\title{
Extraction of common microalgae by liquefied dimethyl ether: influence of species and pretreatment on oil yields and composition
}

\author{
Manuel C. Bauer ${ }^{1}$ (D) $\cdot$ Philipp Konnerth $^{1} \cdot$ Andrea Kruse $^{1}$ (i) \\ Received: 22 July 2020 / Revised: 22 September 2020 / Accepted: 9 October 2020 / Published online: 21 October 2020 \\ (C) The Author(s) 2020
}

\begin{abstract}
Liquefied dimethyl ether (DME) is regarded as a promising, green solvent for biomass lipid extractions. It is non-toxic, applicable to wet feedstocks, and allows easy product separation by pressure reduction. Yet, knowledge about its usability in combination with oleaginous microalgae is limited. In the current work, four common microalgae and cyanobacteria species were used to study DME extraction characteristics: Arthrospira platensis, Nannochloropsis gaditana, Phaeodactylum tricornutum, and Scenedesmus almeriensis. Dried samples were subjected to a batch DME extraction and compared to a standard chloroform/methanol procedure. To evaluate the influence of pretreatment, particle size distributions of two different milling sequences (knife- and cryo-milling) and the resulting effects on DME extraction and oil composition were addressed. Additionally, an algae washing procedure was tested. DME extractions resulted in oil yields of $0.5-2.7 \%$ of dry mass (equal to 5-19\% of total lipids) without further pretreatment. Cryo-milling reduced median particle sizes by $25-87 \%$ and simultaneously increased lipid yields to $1.7-5.6 \%$ of dry mass (17-50\% of total lipids). Phaeodactylum tricornutum showed the highest extraction efficiency with DME, combined with a favorable fatty acid profile. Although being most affected by the additional milling pretreatment, Arthrospira platensis performed worst in both scenarios. DME extracted oils were generally characterized by enhanced contents of C14:0, C16:0, and C16:1 fatty acids. However, relative abundances were strongly influenced by the properties of the tested algae species. The additional cryo-milling pretreatment affected fatty acid compositions by increasing the shares of potentially valuable polyunsaturated fatty acids.
\end{abstract}

Keywords DME $\cdot$ Pressurized liquid extraction $\cdot$ Aquatic biomass $\cdot$ Fatty acid profiles $\cdot$ Biorefinery $\cdot$ Bioeconomy

\section{Introduction}

Algae are considered important biomass source, which will play a crucial role to achieve an industrial transition to a climate-neutral production of chemicals, commodities, and fuels. Depending on species, microalgae can excel yields of land-bound energy plants by a factor of 5 [1] and produce up to 20 times more oil than typical agricultural plants [2]. The downside is very complex and energy-consuming

Electronic supplementary material The online version of this article (https://doi.org/10.1007/s13399-020-01076-3 ) contains supplementary material, which is available to authorized users.

Manuel C. Bauer

Manuel.Bauer@uni-hohenheim.de

1 Department of Conversion Technologies of Biobased Resources, Institute of Agricultural Engineering, University of Hohenheim, Garbenstr. 9, 70599 Stuttgart, Germany photobioreactor systems, especially if the biomass has to meet specific quality standards. Besides, harvesting and dewatering are challenging and energy-consuming tasks $[1,3]$.

Recently, cascade-like biorefinery approaches are being designed in order to obtain multiple marketable products from one algae species. Most concepts rely on different extractions to obtain valuable substances suitable for nutrition, healthcare, or cosmetics [4], prior to a possible end-of-pipe conversion.

During solid-liquid extraction, a targeted compound is transferred from the solid phase (biomass) to an immiscible liquid phase (solvent). In order to be successful, any extraction solvent must be able to penetrate the matrix enclosing the lipid material, make physical contact with the lipid, and solvate the lipid [5]. The process is highly dependent on solvent properties, such as solubility of the targeted compound(s), selectivity, or viscosity [6]. Processing parameters can affect those properties and enhance extraction efficiencies. High flow rates, for example, reduce the boundary layer of concentrated solute at particle surfaces [6] and elevated temperatures may decrease surface tension and viscosity of the solvent [7]. 
Traditionally, organic solvents, such as chloroform, hexane, or dichloromethane, are applied to recover lipids and other valuable compounds from biomass [8, 9]. However, with an increasing need for sustainable and non-toxic extractions, alternative concepts like supercritical fluids, gasexpanded liquids, or switchable solvents arose [7, 10]. The most prominent example, supercritical $\mathrm{CO}_{2}\left(\mathrm{scCO}_{2}\right)$ extraction, has already been applied for several decades. Besides commercial oil recovery from sesame seeds [11] or decaffeination of coffee [12], it has been used to extract various species of microalgae [13-16]. However, feedstocks with high water contents can represent a severe barrier for $\mathrm{scCO}_{2}$ extractions [17] and its low polarity often requires the addition of an entrainer $[15,16]$.

In the case of algae, mechanical dewatering is only viable to about $80 \%$ dry matter and thermal drying requires high amounts of energy [18]. Consequently, particularly the processing of wet feedstocks is a key technology to enable algaesuccess on a large scale $[19,20]$.

Dimethyl ether (DME) offers many major advantages if used as extraction solvent. At normal conditions, DME is a colorless gas (normal boiling point: $-24.82{ }^{\circ} \mathrm{C}$ [21]) with an ethereal odor [22]. It is categorized as non-toxic [23] and only needs a relatively low amount of energy for evaporation and pressurization [24]. The consecutive product separation via pressure reduction is simple and the temperature during extraction is normally set to $20-30{ }^{\circ} \mathrm{C}$, which is mild enough to preserve the most valuable compounds. Furthermore, water is co-extracted and does not inhibit the extraction to a high extent [25] or, in some cases, even enhances the solvent's performance [26]. After DME extraction, a dry biomass residue is left, which contains high amounts of proteins and carbohydrates.

In contrast to many common solvents $[8,18,27,28]$, literature suggests that an energy-intensive pretreatment (e.g., bead milling, microwaving, or steam explosion) can be avoided when DME is used on wet feedstocks [29-31]. If this finding is related to the solvent itself, biomass water content or feedstock properties are largely unknown.

Up to now, DME was applied to multiple species of algae (and cyanobacteria), such as Haematococcus pluvialis [30], Oscillatoria agardhii [32], or Botryococcus braunii [24]. In many cases, oil yields were reported to be comparable with standard extractions [24, 29, 32, 33]. Different blue-green microalgae showed DME recoveries between 97.0 and 99.7\% compared to a common chloroform/methanol procedure [32]. For B. braunii and H. pluvialis, DME yielded $99.1 \%$ and $69.8 \%$ of hexane and acetone extractions, respectively $[24,30]$.

In comparison to $\mathrm{scCO}_{2}$, DME extracted $446 \%$ of oil during the treatment of wet $A$. platensis [34]. Non-microalgae sources, such as tuna liver [35] or labyrinthula Aurantiochytrium limacinum [31], showed recoveries of roughly $100 \%$ and $205 \%$.
To enable an evaluation of different feedstocks under similar processing conditions, the current study relies on a simple batch system. It was assumed that differences in morphological properties, such as cell wall characteristics, lead to specific interactions between solvents and algae. The tested species were Arthrospira platensis (AP, Cyanophyceae), Nannochloropsis gaditana (NG, Eustigmatophyceae), Phaeodactylum tricornutum (PT, Bacillariophyceae), and Scenedesmus almeriensis (SA, Chlorophyceae) [36, 37]. They differ in structure and composition and were used in a dried state. NG, SA, and PT were selected because they offer a combination of high lipid productivity and sufficient content of valuable fatty acids [38-43]. AP was included as it is cultivated all around the world, contains high-quality proteins, and is well known among consumers $[44,45]$.

The four species were extracted with DME and compared to a common Folch based [46, 47] chloroform/methanol Soxhlet procedure with regard to oil yields and oil composition. DME was applied to differently milled samples in order to study the effects of pretreatment. In addition, a simple algae washing procedure [48] was applied and evaluated, which should help to correct biomass ash contents and extraction yield calculations.

Overall, the present work is intended to promote the understanding of the influences of algae species and pretreatment on DME extraction performance and oil quality.

\section{Materials and methods}

\subsection{Microalgae feedstock}

Freeze-dried Nannochloropsis gaditana (NG) and Scenedesmus almeriensis (SA) were obtained from the cultivation facility in Las Palmerillas (University of Almería, Spain). Phaeodactylum tricornutum (PT) slurry was provided by Roquette Klötze GmbH, Germany, and freeze-dried prior to use. Spray-dried Arthrospira platensis (AP) chips originated from the IGV GmbH, Germany. Additional information about the suppliers' drying procedures can be found in Online Resource 2.

\subsection{Milling}

Prior to experiments and analysis, the relatively inhomogeneous biomass samples (pictures of original feedstocks available in Online Resource 1) were milled to uniformity with the help of a knife mill (Pulverisette 19, Fritsch). It was equipped with a stainless steel knife rotor with five "V" shaped blades, which rotates inside the milling chamber (2800 rpm) against three fixed blades until the material passed a $0.5 \mathrm{~mm}$ screen. 
To further reduce the particle size and break open functional cell structures, a part of the samples was subjected to an additional ball milling (CryoMill, Retsch). Here, 5-7 g of knife-milled sample and a ø20 mm stainless steel grinding ball were loaded into a $35 \mathrm{ml}$ grinding jar, which is inserted in the mill to perform radial oscillations in a horizontal position. Automatic pre-cooling and $30 \mathrm{~s}$ intermediate cooling with liquid nitrogen were applied and the samples were milled in two 3 min cycles with at a frequency of $25 \mathrm{~Hz}$.

Figure 1 shows the knife- and cryo-milled algae feedstocks, which were subjected to the extractions.

\subsection{Particle size analysis}

Particle size distributions (PSD) of knife-milled and cryomilled samples were measured by a laser diffraction particle size analyzer (PSA 1190, Anton Paar). Prior to the measurement, microalgae samples were dispersed in ethanol at slow stirring speed and treated with ultrasound at medium stirring speed for $10 \mathrm{~min}$. Measurements were conducted afterward at

\section{knife-milled}

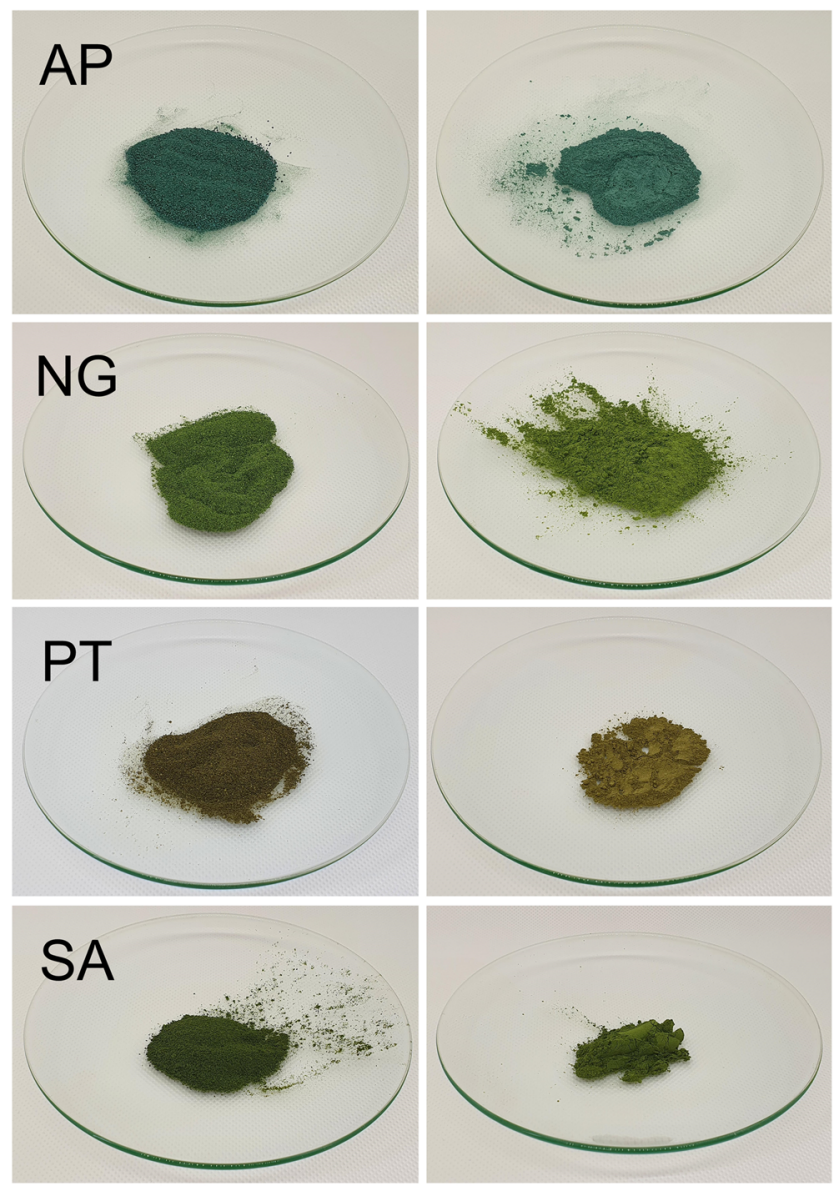

Fig. 1 Knife- and cryo-milled algae feedstocks. AP, Arthrospira platensis; NG, Nannochloropsis gaditana; PT, Phaeodactylum tricornutum; SA, Scenedesmus almeriensis medium stirring speed without further sonication. For each sample, at least two consecutive measurements were done and a mean value was calculated. In addition, mean D10, D50, and D90 values were calculated, which represent equivalent spherical particle diameters of the 10th, 50th, and 90th percentiles of total volume.

\subsection{Algae characterization}

Dry weight of the different microalgae feedstocks with the respective milling pretreatments was determined by drying $0.5 \mathrm{~g}$ of sample at $60^{\circ} \mathrm{C}$ for $48 \mathrm{~h}$ (based on the NREL method NREL/TP-5100-60943) [49]. The determination was done in quadruplicate.

To obtain the ash content, dry samples were subjected to $575^{\circ} \mathrm{C}$ in a muffle furnace according to the NREL algae biomass method (NREL/TP-5100-60956) [50] with three replicates.

Since the ash content of the studied samples was very high in some cases, a washing procedure was tested, which should help to correct dry matter contents in the following calculations (as extraction yields are based on dry matter). In accordance with Zhu and Lee, algae were washed with an isotonic $0.5 \mathrm{M}$ ammonium hydrogen carbonate solution (99\% purity, Acros Organics) [48]. Therefore, $0.3 \mathrm{~g}$ of each species (knifemilled, dry) was mixed with $35 \mathrm{ml}$ of washing solution in a $50 \mathrm{ml}$ falcon tube, vortexed for 20 seconds, and centrifuged for $10 \mathrm{~min}$ at 10,000 rpm under room temperature. The supernatant was vacuum filtrated over a pre-weight, dry $0.2 \mu \mathrm{m}$ filter and washed with an additional $20 \mathrm{ml}$ of ammonium hydrogen carbonate solution. The tube, containing the washed algae pellet, and the filter were dried at $60{ }^{\circ} \mathrm{C}$ for $48 \mathrm{~h}$ and weighed to determine the washed dry matter. This treatment was conducted in triplicate. The ash content of washed samples was determined as stated above.

A CHNS Analyzer (HEKAtech Euro EA, Germany) was used to determine $\mathrm{C}, \mathrm{H}, \mathrm{N}$, and $\mathrm{S}$ contents of washed and unwashed algae samples (dry and finely ground) in duplicate. The oxygen content was calculated by difference.

\subsection{Lipid extraction procedures}

Crude lipid extracts were obtained via modified Folch (2.5.1) and DME (2.5.2) extractions. The experiments were done in triplicate. For a better overview, Fig. 2 contains the applied methods and the most important parameters.

\subsubsection{Soxhlet extraction (modified Folch method, adapted from [46])}

In brief, $2 \mathrm{~g}$ of knife-milled sample was weighed into a cellulose crucible and subjected to a $20 \mathrm{~h}$ extraction with $200 \mathrm{ml}$ of a chloroform/methanol mixture $(2: 1, \mathrm{v} / \mathrm{v})$ in a 


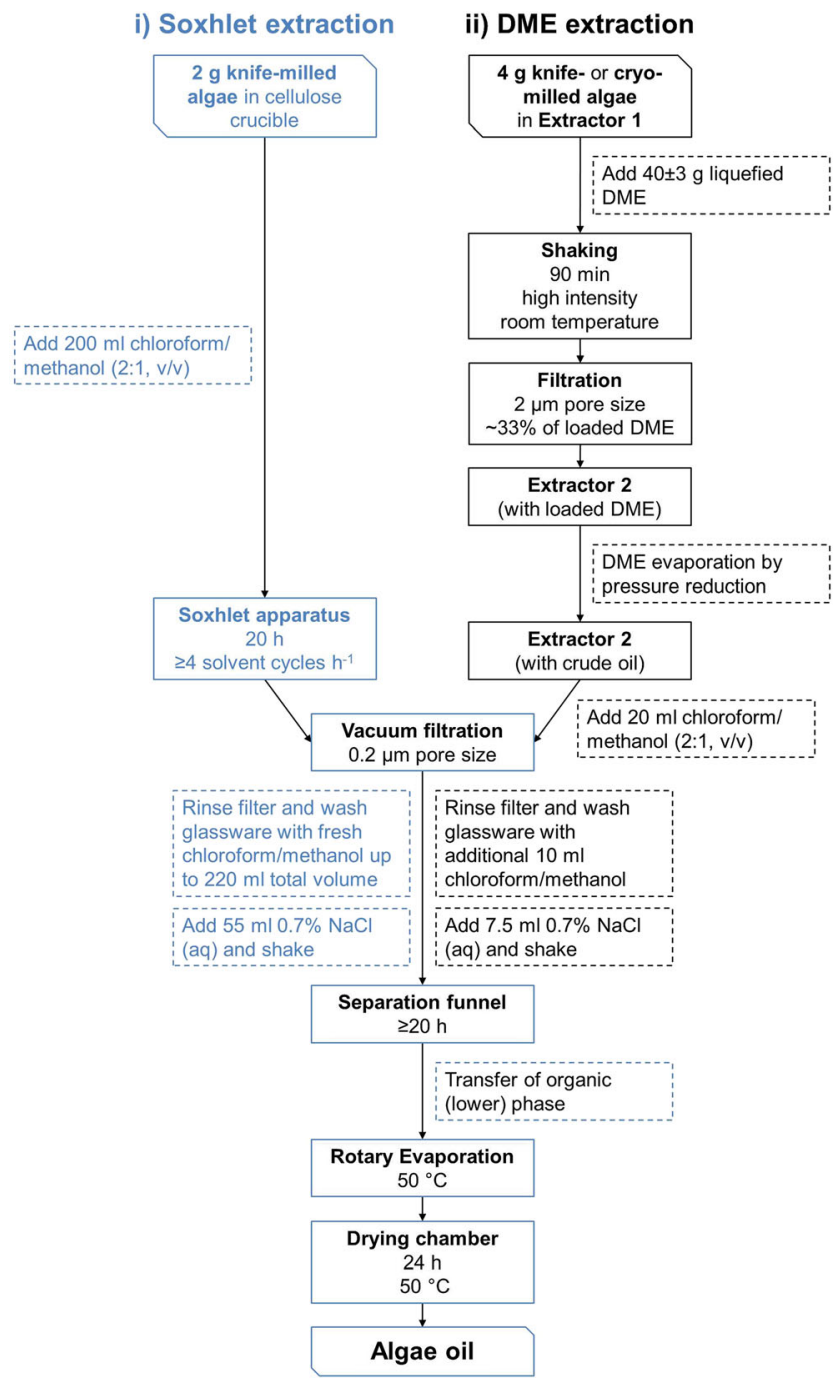

Fig. 2 Applied methods for algae lipid extraction

common Soxhlet apparatus (chloroform was purchased from Merck with $99.0 \%$ purity, methanol from VWR with $\geq 99.9 \%$ purity). Cryo-milled samples were not further investigated here, as the fine particles clumped together and inhibited the extraction in most cases (data not shown). Heating was set to minimum with an Isopad heater (Tyco Thermal Controls) to ensure a number of at least 4 solvent cycles per hour. In the following, the extract was vacuum filtrated $(0.2 \mu \mathrm{m}$ pore size $)$ and filled up to $220 \mathrm{ml}$ with fresh chloroform/methanol $(2: 1, \mathrm{v} / \mathrm{v})$, which was also used to wash the involved glassware and filter three times. After the addition of $55 \mathrm{ml} 0.7 \% \mathrm{NaCl}$ (aq) solution $(99.9 \%$ purity, VWR) up to a final ratio of 8:4:3 chloroform/methanol $/ \mathrm{NaCl}(\mathrm{aq})$, the mixture was shaken and thereafter allowed to settle in a separation funnel for at least $20 \mathrm{~h}$. The lower, organic phase was transferred into a pre-weight flask, evaporated in the rotary evaporator $\left(50^{\circ} \mathrm{C}\right)$, and additionally dried at $50{ }^{\circ} \mathrm{C}$ for $24 \mathrm{~h}$ before the oil yield was determined gravimetrically.

\subsubsection{Dimethyl ether extraction}

For the DME extraction, $4 \mathrm{~g}$ of milled algae (knife- or cryomilled) was loaded into a batch extractor $(80 \mathrm{ml}$, pressureresistant borosilicate glass flask with a screw lid) which was connected to an unlubricated stainless steel valve and mixed with $40 \pm 3$ g of liquefied DME ( $\geq 99.9 \%$ purity, Air Liquide). Figure 3 shows an extractor with dimensions and additional information. The loaded extraction vial was shaken for $90 \mathrm{~min}$ with high intensity (Köttermann 4020 shaker) at room temperature. Pressure occurred as a result of temperature and ranged between roughly $0.5-0.6 \mathrm{MPa}$ [25]. In the following, about one-third of the liquid DME was directed over a $2 \mu \mathrm{m}$ sintered stainless steel filter (FITOK) into a second, empty, pre-weighed extractor vial. The transferred extract was weighed and eventually evaporated naturally.

The leftover oil was solved in $20 \mathrm{ml}$ chloroform/methanol $(2: 1, \mathrm{v} / \mathrm{v})$ and vacuum filtrated $(0.2 \mu \mathrm{m})$. Glass parts and filter were washed with an additional $10 \mathrm{ml}$ of solvent mixture, which was added to the liquid. This combined extract was blended with $7.5 \mathrm{ml}$ of $0.7 \% \mathrm{NaCl}$ (aq) solution (to a final ratio of 8:4:3 chloroform/methanol/ $\mathrm{NaCl}$ (aq)), shaken briefly, and allowed to settle in a separation funnel for at least $20 \mathrm{~h}$.

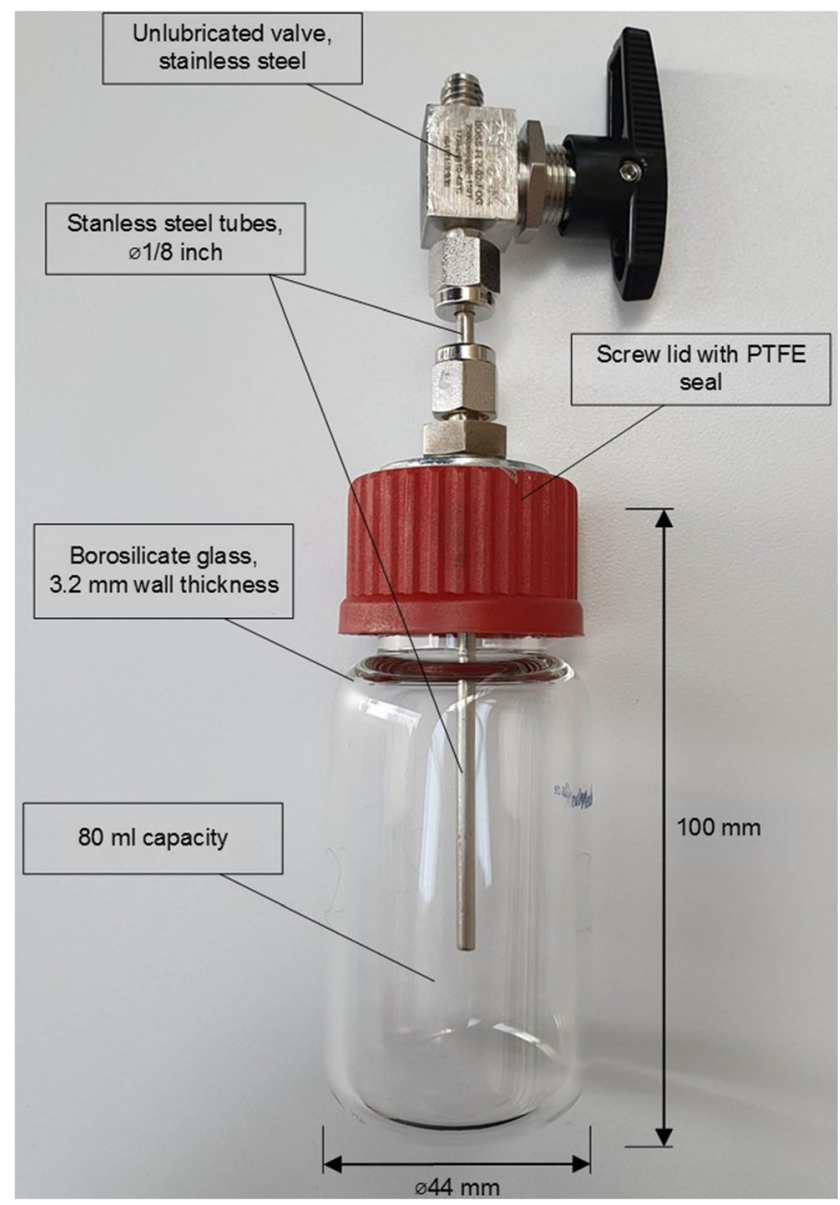

Fig. 3 DME extraction vessel 
The organic phase was transferred into a pre-weight flask. After rotary evaporation $\left(50^{\circ} \mathrm{C}\right)$ and drying the flask at 50 ${ }^{\circ} \mathrm{C}$ for $24 \mathrm{~h}$, the oil yield was determined gravimetrically and calculated back onto the total amount of oil solved in the original flask and the total extraction yield according to formulas (1) and (2):

$m_{t}=\frac{m_{\mathrm{DME} 1}}{m_{\mathrm{DME} 2}} \times m_{\mathrm{Oil} 2}$

where $m_{t}$ is the mass of total oil extracted (g); $m_{\mathrm{DME} 1}$ is the mass of DME in first extractor vial (g); $m_{\mathrm{DME} 2}$ is the mass of DME in second extractor vial (g); $m_{\text {Oil } 2}$ is the mass of oil in second extractor vial $(\mathrm{g})$.

$M_{t}=\frac{m_{t}}{m_{a}} \times 100$

where $M_{t}$ is the total oil yield (\% of algae dry mass); $m_{t}$ is the mass of total oil extracted $(\mathrm{g}) ; m_{a}$ is the mass of dry microalgae used (g).

\subsection{Fatty acid profile analysis}

To determine the fatty acid profiles, mixed oil samples of at least three identical extraction trials were prepared. They were solved in chloroform immediately after weighing and stored at $4{ }^{\circ} \mathrm{C}$ prior to analysis.

The following sample preparation consisted of evaporation of the chloroform, hydrolysis with $0.1 \mathrm{M}$ hydrochloric acid $(40 \mathrm{ml}$ per $g$ oil) for $1 \mathrm{~h}$, filtration (filter paper MN 715 1/4, MachereyNagel), and neutralization with cold water. Extraction of the fatty acids was carried out on the dried retentate with petroleum ether for $6 \mathrm{~h}$ in a Soxhlet apparatus $\left(30-50^{\circ} \mathrm{C}\right)$. Then, $0.2-0.3 \mathrm{~g}$ of the pretreated, dried sample extract was dissolved in $5 \mathrm{ml}$ of diisopropyl ether. Subsequent methylation was done by adding a $0.2 \mathrm{M}$ methanolic solution of trimethylsulfoniumhydroxide (TMSH) to an aliquot of the sample extract dissolved in diisopropyl ether in a ratio of 1:2(v/v). For analysis, this mixture was injected into a GC with FI detection (7890A, Agilent Technologies), equipped with a capillary column DB-23, $30 \mathrm{~m}$ $\times 0.250 \mathrm{~mm}$, film $0.25 \mu \mathrm{m}$ (Agilent Technologies).

The fatty acid standard mixture to be used for calibration consists of 37 individual components (C4:0 to $\mathrm{C} 24: 1)$. The amount of a methyl ester in \% was calculated by determining the percentage corresponding to its peak area relative to the total sum of all FAME peak areas in the chromatogram. The calculated value was expressed as \% relative to the total fatty acids.

\subsection{Data evaluation}

For each of the experiments (excluding GC-FID analysis), samples of a larger amount of homogenized feedstock were used. In the cases of elemental analysis and particle size distribution, the respective analyses were carried out in duplicate according to established best-practiced methods and a mean value was calculated. The other experiments' results were expressed as the average of at least three independent trials. In the case of the extraction experiments, standard deviations were additionally presented to allow an estimation of measurement uncertainties, mainly associated with the manual use of a separation funnel and the very low amount of product generated during each step.

\section{Results}

In the following sections, $\%$ represents $g 100 \mathrm{~g}^{-1}$ dry weight unless stated differently. First, the influence of feedstock is reported.

\subsection{Feedstock}

Table 1 contains basic data about the microalgae from characterization experiments and literature.

Dry matter contents of all feedstocks ranged between 95.3 and $97.5 \%$ and only small differences could be found between cryo-milled and knife-milled samples.

According to literature, NG and PT show lipid yields between roughly 20 and $32 \%$ and SA between 11 and $22 \%$. Even though AP was also reported to yield up to $16 \%$, it is usually rather settled in the 4-9\% region. Considering proteins, up to $70 \%$ can be found in AP, while PT ranks lowest with around $37 \%$.

The results of the elemental analysis (not-washed feedstocks) displayed that the carbon contents of AP and SA were located at nearly $50 \%$. In contrast, PT and NG showed remarkably lower $\mathrm{C}$ contents with $41.2 \%$ and $34.8 \%$, respectively. Nitrogen contents of the tested species ranged between 5.1 and $10.0 \%$. The amounts of oxygen, hydrogen, and sulfur were relatively similar between the algae.

A large difference among the species could be identified for the ash contents. Especially NG and PT showed high values for ash (27.0\% and 16.7\%), while SA was settled at 9.9\% and AP at only $6.2 \%$.

\subsection{Pretreatments}

\subsubsection{Algae washing}

Washing with ammonium hydrogen carbonate solution reduced the ash content and consequently increased the proportions of $\mathrm{C}$, $\mathrm{H}$, and $\mathrm{N}$ in all cases (Table 1). The most remarkable increase was observed in the $\mathrm{C}$ content of $\mathrm{NG}$ and accounted for nearly $10.4 \%$. At the same time, in three of the four species (except for $\mathrm{NG}$ ), the proportion of $\mathrm{O}$ was lower after washing. Figure 4 
Table 1 Properties of microalgae feedstocks (own experiments and literature data). Own values are expressed as a mean of two (elemental analysis) and three (dry weight determination) replicates

\begin{tabular}{|c|c|c|c|c|c|c|c|c|}
\hline & \multicolumn{2}{|c|}{$\begin{array}{l}\text { Arthrospira platensis } \\
\text { (AP) }\end{array}$} & \multicolumn{2}{|c|}{$\begin{array}{l}\text { Nannochloropsis gaditana } \\
\text { (NG) }\end{array}$} & \multicolumn{2}{|c|}{$\begin{array}{l}\text { Phaeodactylum tricornutum } \\
\text { (PT) }\end{array}$} & \multicolumn{2}{|c|}{$\begin{array}{l}\text { Scenedesmus almeriensis } \\
\text { (SA) }\end{array}$} \\
\hline & \multicolumn{8}{|c|}{ Pretreated with knife mill (K) or cryo-mill (C) } \\
\hline & $\mathrm{K}$ & $\mathrm{C}$ & $\mathrm{K}$ & $\mathrm{C}$ & $\mathrm{K}$ & $\mathrm{C}$ & $\mathrm{K}$ & $\mathrm{C}$ \\
\hline \multirow[t]{3}{*}{ Dry weight (g $100 \mathrm{~g}^{-1}$ fresh weight) } & 95.30 & 95.95 & 97.44 & 97.49 & 95.96 & 96.74 & 96.54 & 96.41 \\
\hline & \multicolumn{8}{|c|}{ Literature values } \\
\hline & $4.0-16.0^{\mathrm{i}}$ & & $22.0-2$ & & $20.0-3$ & & $11.2-2$ & \\
\hline \multirow[t]{3}{*}{ Proteins $(\%)$} & $46.0-70.0^{\mathrm{v}}$ & & $36.0-4$ & & $36.4-3$ & & $41.8-5$ & \\
\hline & \multicolumn{8}{|c|}{ Not-washed (-) or washed** (w) feedstock } \\
\hline & - & $\mathrm{w}$ & - & $\mathrm{w}$ & - & $\mathrm{w}$ & - & $\mathrm{w}$ \\
\hline $\mathrm{C}(\%)$ & 48.10 & 50.23 & 34.77 & 45.15 & 41.23 & 44.36 & 46.67 & 50.05 \\
\hline $\mathrm{H}(\%)$ & 6.78 & 7.31 & 5.11 & 6.72 & 6.05 & 6.70 & 6.69 & 7.23 \\
\hline $\mathrm{N}(\%)$ & 9.95 & 11.43 & 5.07 & 7.01 & 6.75 & 8.12 & 7.05 & 8.28 \\
\hline $\mathrm{S}(\%)$ & 0.55 & 0.52 & 0.82 & 1.09 & 0.87 & 0.96 & 0.94 & 0.75 \\
\hline $\mathrm{O}(\%)^{*}$ & 28.39 & 27.49 & 27.27 & 31.69 & 28.43 & 26.96 & 28.76 & 27.38 \\
\hline Ash (\%) & 6.23 & 3.02 & 26.97 & 8.33 & 16.67 & 12.90 & 9.89 & 6.31 \\
\hline
\end{tabular}

*Calculated by difference

**Washing conducted with knife-milled samples

i-viii References: ${ }^{\mathrm{i}}[45,51,52],{ }^{\mathrm{ii}}[53-56],{ }^{\mathrm{iii}}[43,55-58],{ }^{\mathrm{iv}}[36,55,59],{ }^{\mathrm{v}}[45,51,52],{ }^{\mathrm{vi}}[53,55],{ }^{\text {vii }}[52,55],{ }^{\text {viii }}[55,59]$

shows ash contents and ash-free dry mass (mass DAF) of all algae tested in $\%$ of initial dry mass.

Decreases of ash contents ranged between $3.8 \%$ (AP) and $22.2 \%(\mathrm{NG})$ of initial dry mass. PT and SA values were reduced by $7.5 \%$ and $4.7 \%$ of initial dry mass (Fig. 4). The lowest ash content after washing was measured in AP, while PT ranked highest (Table 1).

At the same time, ash-free dry mass was also removed during the washing. This led to further losses of $15.1 \%$, $20.8 \%, 12.7 \%$, and $21.3 \%$ of initial dry mass for AP, NG, SA, and PT. Alternative trials with two consecutive washing cycles led to greater removal of ash-free dry mass (Data not shown).

\subsubsection{Algae milling}

Table 2 and Fig. 5 contain the volume-based results of D10, D50, and D90 values and particle size distributions for knifemilled and cryo-milled algae samples, respectively.

Varying particle size distributions were found among the different feedstocks after both milling pretreatments.

PSD of knife-milled AP showed a peak at $400 \mu \mathrm{m}$ and a median particle size (D50) of $171.5 \mu \mathrm{m}$, meaning that $50 \%$ of the particles had a size $\leq 171.5 \mu \mathrm{m}$. The other three species (knife-milled) consisted of smaller particles and peaked at $63 \mu \mathrm{m}$ (NG and PT) and $75 \mu \mathrm{m}$ (SA). Median particle sizes were also considerably lower with 39.0-54.3 $\mu \mathrm{m}$.

For each sample, a small particle fraction between 0.2 and $0.8 \mu \mathrm{m}$ was found, which was increased after cryo-milling (except for NG). It also decreased median particle sizes significantly to $12.2-33.7 \mu \mathrm{m}$. PSD curves of AP and SA were changed drastically (new maxima at $50 \mu \mathrm{m}$ and $14 \mu \mathrm{m}$, respectively), whereas PT was less impacted (new maximum at $50 \mu \mathrm{m})$. The NG maximum was retained at $63 \mu \mathrm{m}$, but the number of particles in this size-division was reduced.

\subsection{Lipid extraction}

In Fig. 6, crude oil yields are shown for the Soxhlet and DME extractions.

The Soxhlet (Folch) method with knife-milled feedstocks is expected to provide a good approximation of total lipid biomass contents and will be considered "total extractable oil" in the following.

Soxhlet oil yields ranged from $9.7 \%(\mathrm{NG})$ to $15.9 \%$ (SA) of dry mass. DME showed yields of $0.5 \%$ (AP) to $2.7 \%$ (SA) for knife-milled and $1.7 \%$ (AP) to $5.6 \%$ (SA) for cryo-milled feedstocks.

Of the tested species, AP revealed the lowest compatibility with the DME extraction procedure. Depending on pretreatment, extraction efficiencies between 5\% (knife-milled) and $17 \%$ (cryo-milled) were realized by DME. NG yielded 8-18\% and SA $17-35 \%$ for knife- and cryo-mill pretreatments, respectively. The highest efficiencies were achieved with PT, which ranged from $19 \%$ (knife-milled) to 50\% (cryo-milled). Milling increased the yields in each case but showed different changes depending on the species. AP was most influenced, as DME yields increased by a factor of 3.5. PT, NG, and SA recoveries were 
Fig. 4 Ash content and ash-free dry mass (mass DAF) of notwashed (-) and washed (w) algae as $\%$ of initial dry mass. Values are expressed as a mean of three replicates

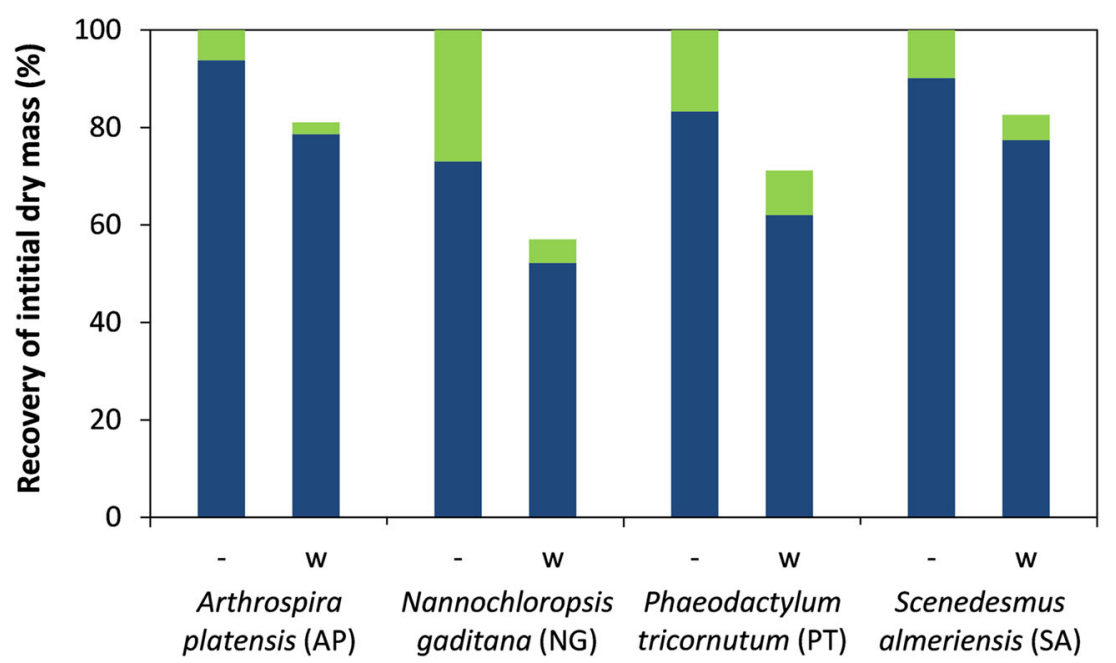

Algae species and pretreatment

mass DAF Ash enhanced by factors of 2.0-2.6 by the additional milling. Each of the extracts with either method was colored in a dark greenishbrown and characterized by a high viscosity at room temperature.

\subsection{Fatty acid compositions}

Table 3 contains the fatty acid compositions of the extracted oils.

The four algae species displayed major differences in fatty acid compositions. Palmitic acid (C16:0) was found in every alga, although only for AP it was the main fatty acid with shares of 56.0-63.6\%. Linoleic acid (C18:2n6) and $\gamma$ linolenic acid (GLA, C18:3n6) ranged between 11.7 and $14.9 \%$ and 9.3 and $12.6 \%$ for this species.

In NG and SA oils, $\alpha$-linolenic acid (C18:3n3) was dominant with shares between $41.7-45.0 \%$ and $41.8-51.0 \%$, respectively. Both species showed a relatively similar fatty acid profile with the remaining major fatty acids being C16:0, C16:1, C18:1n9, and C18:2n6.

For PT, C16:1 (31.5-37.5\%) and C16:0 (23.0-28.6\%) were dominant. In addition, eicosapentaenoic acid (EPA, C20:5n3) could be found in significant quantities (11.2-18.5\%).

The total polyunsaturated fatty acids (PUFA) content of AP (about 23-27\%) was roughly doubled by NG (56-59\%). SA ranked highest with $55-65 \%$ and PT lowest with only 14 $22 \%$. However, in contrast to the other three species, EPA was the dominant fatty acid and represented around $80 \%$ of the PUFA extracted from PT.

Concerning saturated fatty acids, AP oil contained by far the highest share (60-67\%), followed by PT (36-42\%), NG (30-34\%), and SA (15-25\%). Monounsaturated fatty acids were highest in PT (40-44\%) and lowest in AP (7-13\%).

The method of extraction and the respective solvents affected fatty acid compositions. With regard to the total numbers of saturated and monounsaturated fatty acids in knife-milled extractions, DME showed higher shares in AP and PT (approx. $+5 \%$ ), was about even in NG, and around 9\% lower in SA. Total PUFA shares behaved vice versa. In addition, DME led to an increase in relative contents of $\mathrm{C} 14: 0$ and $\mathrm{C} 16: 0$ for $\mathrm{AP}, \mathrm{NG}$, and $\mathrm{PT}$ and in relative content of $\mathrm{C} 16: 1$ for $\mathrm{AP}, \mathrm{PT}$, and $\mathrm{SA}$.

The effect of cryo-milling prior to DME extraction was apparent: total PUFA shares increased in each case, while the proportion of saturated and monounsaturated fatty acids was either nearly constant or decreased. This was by far most pronounced in PT, where the EPA share increased from 11.2 to $18.5 \%$ and total PUFA from 14.2 to $22.1 \%$ after cryo-milling.
Table 2 Calculated mean values of at least 2 replicates for 10th (D10), 50th (D50), and 90th (D90) percentiles of total volume for knife-milled (K) and cryomilled (C) algae samples

\begin{tabular}{|c|c|c|c|c|c|c|c|c|}
\hline & \multicolumn{2}{|c|}{$\begin{array}{l}\text { Arthrospira } \\
\text { platensis (AP) }\end{array}$} & \multicolumn{2}{|c|}{$\begin{array}{l}\text { Nannochloropsis } \\
\text { gaditana }(\mathrm{NG})\end{array}$} & \multicolumn{2}{|c|}{$\begin{array}{l}\text { Phaeodactylum } \\
\text { tricornutum (PT) }\end{array}$} & \multicolumn{2}{|c|}{$\begin{array}{l}\text { Scenedesmus } \\
\text { almeriensis (SA) }\end{array}$} \\
\hline & K & $\mathrm{C}$ & K & $\mathrm{C}$ & K & $\mathrm{C}$ & K & $\mathrm{C}$ \\
\hline $\mathrm{D} 10(\mu \mathrm{m})$ & 17.1 & 2.6 & 5.4 & 3.3 & 4.9 & 2.5 & 7.8 & 2.3 \\
\hline $\mathrm{D} 50(\mu \mathrm{m})$ & 171.5 & 21.6 & 45.0 & 33.7 & 39.0 & 18.1 & 54.3 & 12.2 \\
\hline $\mathrm{D} 90(\mu \mathrm{m})$ & 399.5 & 96.3 & 99.7 & 106.6 & 91.2 & 60.8 & 146.9 & 43.4 \\
\hline
\end{tabular}


Fig. 5 Particle size distribution (PSD) of knife-milled (K) and cryo-milled (C) algae samples. Values are expressed as a mean of at least two replicates
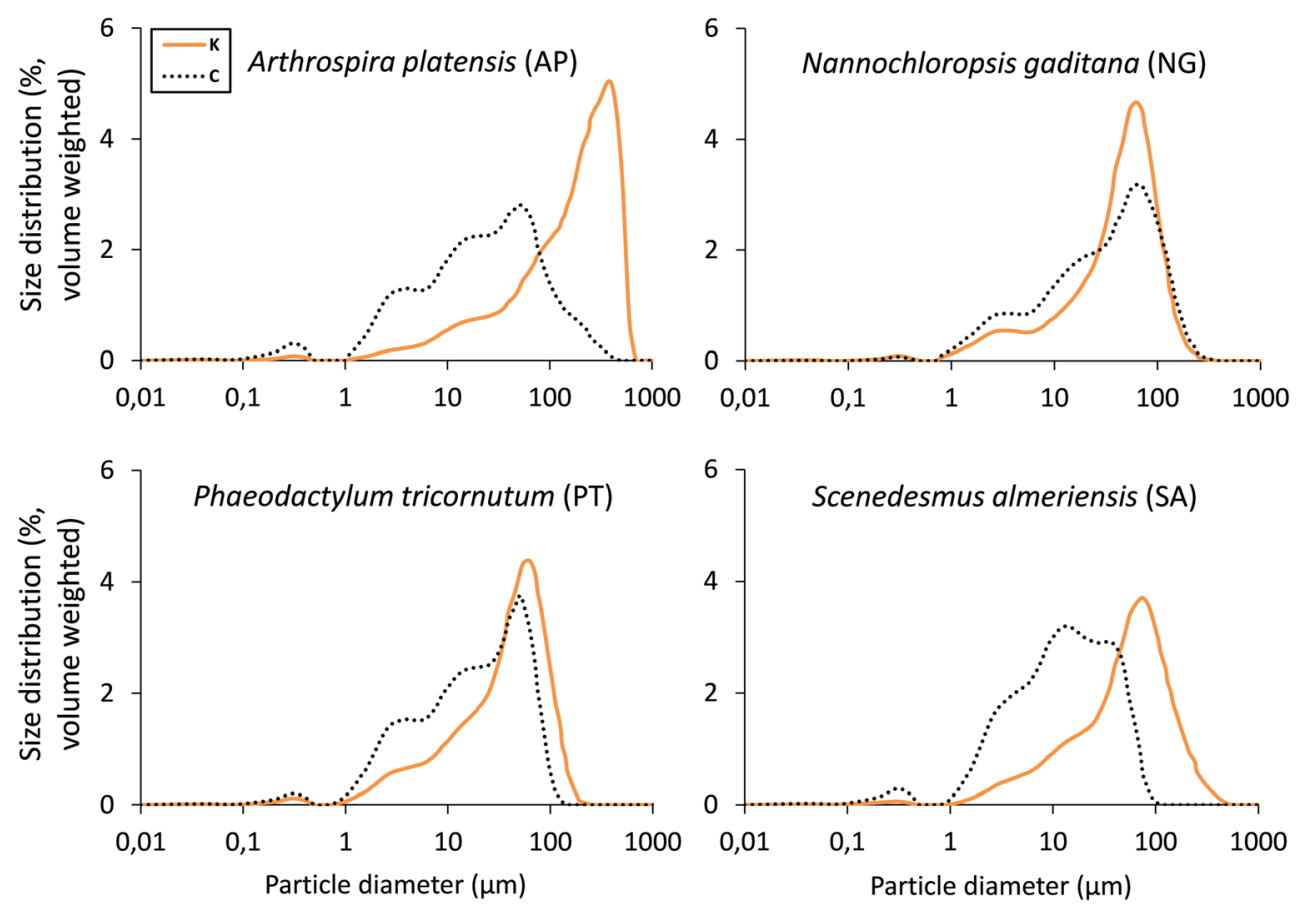

\section{Discussion}

\subsection{Feedstock}

Regarding the biomass water contents, cryo-milling only led to negligible changes for the tested samples (Table 1).

For both of the applied extraction methods, water can be tolerated to a certain extent. DME is miscible with water but may undergo a change of polarity, depending on the ratio of solvent to water $[60,61]$. The applied chloroform/methanol system $(2: 1, \mathrm{v} / \mathrm{v})$ is also applicable with small amounts of water but exhibits a phase separation above $3 \%$ water in the solvent mixture [62]. Also, in the case of wet biomass, a solvent shell can be formed, which may inhibit the extraction by the less polar chloroform [5]. Consequently, as the influences of biomass water contents on both extraction systems are expected to be high, only dried, stable feedstocks were tested. In this way, the effects of solvents and pretreatments on yields and composition of the oils could be studied and water-induced side effects and interferences were minimized.
Fig. 6 Crude oil yields (\% dry mass) of algae extracted via chloroform/methanol (Soxhlet, knife-milled) and liquefied dimethyl ether (DME, knife- and cryo-milled). Values are expressed as a mean of three replicates; error bars represent standard deviation

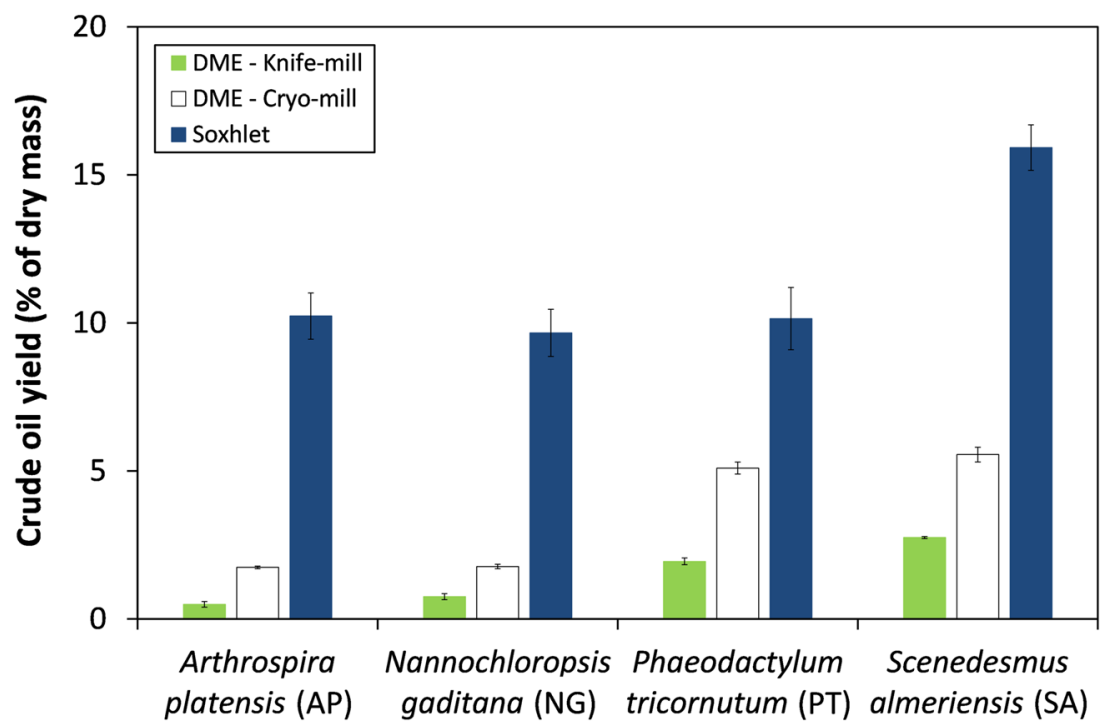

Algae species 
Table 3 Fatty acid profiles (\% of total fatty acids) of dimethyl ether (DME) and chloroform/methanol (Soxhlet) extracted oils. $K$, knife-milled algae feedstock; $C$, cryo-milled algae feedstock; $S F A$, saturated fatty acids; $M U F A$, monounsaturated fatty acids; $P U F A$, polyunsaturated fatty acids; - , below $0.01 \%$ of total analyzed fatty acids

\begin{tabular}{|c|c|c|c|c|c|c|c|c|c|c|c|c|}
\hline & \multicolumn{3}{|c|}{ Arthrospira platensis (AP) } & \multicolumn{3}{|c|}{ Nannochloropsis gaditana (NG) } & \multicolumn{3}{|c|}{ Phaeodactylum tricornutum (PT) } & \multicolumn{3}{|c|}{ Scenedesmus almeriensis (SA) } \\
\hline & \multirow{2}{*}{$\begin{array}{l}\text { Soxhlet } \\
\text { K }\end{array}$} & \multicolumn{2}{|l|}{ DME } & \multirow{2}{*}{$\begin{array}{l}\text { Soxhlet } \\
\text { K }\end{array}$} & \multicolumn{2}{|l|}{ DME } & \multirow{2}{*}{$\begin{array}{l}\text { Soxhlet } \\
\text { K }\end{array}$} & \multicolumn{2}{|l|}{ DME } & \multirow{2}{*}{$\begin{array}{l}\text { Soxhlet } \\
\text { K }\end{array}$} & \multicolumn{2}{|l|}{ DME } \\
\hline & & K & $\mathrm{C}$ & & $\mathrm{K}$ & $\mathrm{C}$ & & K & $\mathrm{C}$ & & K & $\mathrm{C}$ \\
\hline $\mathrm{C} 4: 0$ & 0.20 & 0.02 & - & 0.05 & - & 0.14 & - & 0.02 & - & 0.05 & - & - \\
\hline C6:0 & - & - & - & - & - & 0.03 & - & - & - & - & - & - \\
\hline $\mathrm{C} 8: 0$ & - & 0.05 & - & - & - & 0.07 & - & - & - & - & - & - \\
\hline $\mathrm{C} 10: 0$ & - & 0.40 & - & - & - & 0.06 & - & - & - & - & - & - \\
\hline C11:0 & - & - & - & - & - & - & - & - & - & - & - & - \\
\hline C12:0 & - & 0.20 & 0.10 & - & - & 0.12 & - & 0.04 & 0.02 & - & - & - \\
\hline C13:0 & - & - & - & - & - & - & - & - & 0.03 & - & - & - \\
\hline C14:0 & 0.40 & 0.54 & 0.51 & 0.77 & 1.06 & 0.88 & 8.24 & 10.80 & 8.67 & 0.50 & 0.50 & 0.30 \\
\hline C14:1 & - & & & 0.02 & 0.02 & - & 0.14 & 0.35 & 0.04 & - & 0.02 & 0.02 \\
\hline C15:0 & 0.19 & 0.18 & 0.19 & 0.47 & 0.55 & 0.53 & 0.46 & 0.58 & 0.48 & 0.13 & 0.12 & 0.10 \\
\hline C15:1 & - & - & - & - & - & - & - & - & - & - & - & - \\
\hline $\mathrm{C} 16: 0$ & 56.02 & 61.19 & 63.60 & 21.14 & 21.99 & 19.29 & 23.03 & 28.58 & 25.43 & 21.59 & 13.79 & 13.31 \\
\hline C16:1 & 5.75 & 6.03 & 6.43 & 4.82 & 2.96 & 2.54 & 31.54 & 37.54 & 35.19 & 5.39 & 6.04 & 5.61 \\
\hline $\mathrm{C} 17: 0$ & 0.76 & 0.59 & 0.67 & 0.86 & 0.63 & 0.31 & 6.45 & - & - & 0.49 & 0.50 & 0.41 \\
\hline $\mathrm{C} 17: 1$ & 0.67 & - & 0.87 & 0.91 & - & 0.19 & 1.69 & - & - & 0.43 & - & 0.05 \\
\hline C18:0 & 2.26 & 1.92 & 1.80 & 2.66 & 3.30 & 2.48 & 1.18 & 0.60 & 0.71 & 1.34 & 0.88 & 0.87 \\
\hline $\mathrm{C} 18: 1 \mathrm{n} 9$ & 6.22 & 6.25 & - & 4.21 & 9.71 & 8.88 & 4.52 & 4.65 & 4.54 & 14.28 & 14.18 & 14.85 \\
\hline C18:2n6 & 14.00 & 11.72 & 14.86 & 13.30 & 12.31 & 12.63 & 1.21 & 1.06 & 1.57 & 12.28 & 13.08 & 12.81 \\
\hline $\mathrm{C} 18: 3 n 3$ & 0.18 & 0.27 & 0.08 & 41.66 & 42.88 & 44.95 & 0.38 & 0.38 & 0.44 & 41.79 & 49.69 & 51.02 \\
\hline C18:3n6 & 12.62 & 9.75 & 9.29 & - & 0.07 & 0.09 & 0.55 & 0.45 & 0.59 & 0.40 & 0.28 & 0.28 \\
\hline C20:0 & 0.15 & 0.14 & 0.19 & 6.52 & 3.27 & 4.41 & 0.10 & 0.09 & 0.06 & 0.06 & 0.06 & 0.03 \\
\hline C20:1 & 0.18 & 0.17 & 0.15 & 0.29 & 0.28 & 0.15 & 0.57 & 0.09 & - & 0.24 & 0.16 & 0.22 \\
\hline C20:2 & 0.18 & 0.18 & 0.20 & 0.04 & - & 0.21 & 0.18 & 0.10 & 0.11 & - & - & 0.02 \\
\hline $\mathrm{C} 20: 3 \mathrm{n} 3$ & 0.24 & 0.17 & 0.23 & - & - & - & - & 0.06 & 0.05 & - & - & - \\
\hline C20:3n6 & - & - & - & 0.14 & 0.15 & 0.18 & - & - & - & 0.07 & - & 0.03 \\
\hline C20:4n6 & - & - & - & - & - & - & 0.63 & 0.47 & 0.71 & - & - & - \\
\hline $\mathrm{C} 20: 5 \mathrm{n} 3$ & - & 0.59 & 0.72 & 0.44 & 0.23 & 0.43 & 16.30 & 11.22 & 18.54 & 0.13 & 0.46 & 0.29 \\
\hline C21:0 & - & - & - & - & 0.16 & 0.20 & 0.37 & - & - & - & - & - \\
\hline $\mathrm{C} 22: 0$ & - & - & - & 1.27 & 0.44 & 0.75 & 0.20 & 0.08 & 0.11 & 0.59 & 0.26 & 0.47 \\
\hline $\mathrm{C} 22: 1 \mathrm{n} 9$ & - & - & - & - & - & - & - & 0.44 & 0.04 & - & - & - \\
\hline C22:2 & - & - & - & - & - & 0.28 & - & - & - & - & - & 0.15 \\
\hline $\mathrm{C} 22: 6 \mathrm{n} 3$ & - & - & - & - & - & - & - & 0.46 & 0.13 & - & - & - \\
\hline C23:0 & - & - & 0.14 & 0.44 & - & - & - & - & - & 0.25 & - & - \\
\hline $\mathrm{C} 24: 0$ & - & - & - & - & - & 0.25 & 1.07 & 1.29 & 0.93 & - & - & - \\
\hline C24:1 & - & - & - & - & - & - & 1.20 & 0.67 & - & - & - & - \\
\hline$\sum \mathrm{SFA}$ & 59.98 & 65.23 & 67.20 & 34.18 & 31.40 & 29.52 & 41.10 & 42.08 & 36.44 & 25.00 & 16.11 & 15.49 \\
\hline$\sum$ MUFA & 12.82 & 12.45 & 7.45 & 10.25 & 12.97 & 11.76 & 39.66 & 43.74 & 39.81 & 20.34 & 20.40 & 20.75 \\
\hline$\sum$ PUFA & 27.22 & 22.68 & 25.38 & 55.58 & 55.64 & 58.77 & 19.25 & 14.20 & 22.14 & 54.67 & 63.51 & 64.60 \\
\hline
\end{tabular}

However, with regard to a final application, systems that can tolerate high water contents are highly desirable [19, 20]. Experiments with varying water contents will be part of a consecutive study.
With a view of previously reported lipid values, only the Soxhlet trials of AP and SA lie in the expected region (Table 1 and Fig. 6). The yield of NG revealed to be less than half of the predicted value. This finding, combined with the fatty acid 
profile found for NG (Table 3) led to the conclusion that the feedstock was most likely fundamentally different from a usual Nannochloropsis gaditana or heavily contaminated during cultivation (also see 4.4). Most other differences between reported and measured values can be owed to additional factors that influence microalgae compositions, such as subspecies, culture conditions (e.g., starvation, light regime, culture medium), and culture age [63, 64].

AP showed the highest nitrogen concentration, which correlates well with the expected, high protein content [44, 45]. The overall low contents of $\mathrm{C}, \mathrm{H}$, and $\mathrm{N}$ found in $\mathrm{NG}$ can be explained by the very high amount of ash. It accounted for over $25 \%$, which results in a lower proportion of biomass constituents and calculated extraction efficiency. Ash contents of PT and SA were also relatively high, but the effect was less pronounced.

The marine species NG and PT are mostly cultivated in saline media. It is well known that the growth media has a high impact on cell composition of microalgae [65] and that salts can be absorbed on the cell surface and/or be solved in intercellular water [48]. To further address this issue, algae washing was conducted.

\subsection{Pretreatments}

\subsubsection{Algae washing}

The washing was mainly conducted in order to minimize the effects of adsorbed salts or non-cellular suspended solids (e.g., calcium carbonate) [66] on oil extraction yield calculations. For each of the tested species, washed samples showed lower ash contents than untreated ones, which suggests a successful removal. As a consequence, the relative contents of $\mathrm{C}, \mathrm{H}$, and $\mathrm{N}$ increased (Table 1). Only oxygen was rather unchanged, which can partly be explained by the nature of some common salts which are expected to have been washed out (e.g., $\mathrm{Na}_{2} \mathrm{SO}_{4}, \mathrm{NaNO}_{3}$ ) [67]. The washing was very effective for the marine species-especially from NG and to a smaller extent from PT, substantial parts of ash were removed.

However, simultaneously, a large proportion of ash-free dry mass was lost during the treatment of each species (Fig. 4). After the washing, between 71 and $83 \%$ of the original biomass dry mass were left for AP, PT, and SA. In all three cases, the impact of mass DAF removal on total weight after washing was greater than the impact of ash removal. The most extreme result was obtained for NG, where only $57 \%$ of the original biomass retained.

It can be assumed that the algal cells of each of the tested species were already (partly) damaged during the drying or knife-milling and in this way also organic cell constituents were removed. Algae drying, for example, may already lower cells' elasticity, as shown by Miranda et al. in a study with Scenedesmus obliquus [68].

In contrast to the applied procedure, algae were washed directly after harvesting in previous works $[48,55,69]$. In this way, cells were presumably still intact. For the presented feedstocks, algae washing was not suitable as a pre-processing step and was not included in further calculations.

\subsubsection{Algae milling}

In the present work, grinding in liquid nitrogen (cryo-milling) was applied to avoid excessive heat (and destruction or reduction of desired products [70]), as well as effectively disrupt algal cells in a relatively short time [71]. This ensured a high accuracy during the experiments but is not suitable for largescale application.

Algae cell walls often form strong barriers to solvents, which have to make physical contact with the lipids in order to successfully solvate them [5]. Cell wall architecture and composition and consequently the resistance to physical or chemical stresses among different algae and cyanobacteria are highly variable $[8,68,70]$. In addition, culture conditions can have a large impact on the biomass quality, as they do not only influence lipid synthesis and salt content but can also directly impact cell wall thickness and stability [72].

Crucial differences can be noted in the cell wall architecture of the applied species. AP is a cyanobacterium with a sixlayered wall. Its inner cell membrane is covered by a peptidoglycan layer, which is located between two fibrillary layers. The outer membrane is covered with a sheath of acidic polysaccharides and tightly connected to the peptidoglycan layer [70].

NG and SA both obtain cellulose layers and algaenancontaining layers. The latter are insoluble, nonhydrolysable, highly resistant aliphatic polymers of distinct biochemical origin. They are believed to be primarily responsible for the cell's robustness, but their composition varies between algal species $[70,73]$.

In particular, the plasma membrane of NG is connected to a thick, porous, cellulose-based layer via struts. It is protected by an algaenan layer with extensions that protrude from the surface. The Scenedesmus cell wall consists of an inner cellulosic layer that surrounds the membranes of individual cells and a thin, algaenan-based trilaminar sheath [74]. It is often described as extremely robust $[68,74,75]$ and highly resistant to bacterial degradation [75], chemical attacks [68], and lytic enzymes [74].

PT exhibits major differences in composition, surface ultrastructure, and mechanical properties depending on morphotype [76, 77]. Ovoid cell walls, for example, are strongly silicificated and about five times stiffer than other types [76]. 
Martínez-Sanz et al. showed that Spirulina cells could simply be disrupted by stirring, whereas Nannochloropsis gaditana and Scenedesmus almeriensis required intense sonication [78]. Such a need for cell rupture was reported repeatedly during extractions of different components from NG, PT, and SA, such as pigments [79-83], amino acid concentrates [59] or lipids [81, 84].

It is commonly assumed that peptidoglycan-based cell walls, like in the case of AP, are softer than cellulosecontaining ones [85]. This relationship was confirmed in the present measurements. AP median particle size was reduced by $87 \%$ (Fig. 5 and Table 2), followed by SA (reduction of $76 \%$ ), PT (54\%), and NG (25\%). A similar trend was observed for the PSD spectra (Fig. 5). NG and PT curves appeared rather unchanged with a maximum of particles close to the original value and some smaller fractions becoming more prevalent. In contrast, the SA and AP curves were completely shifted towards smaller particle sizes. The appearance of a higher number of particles below the size of a single cell is an indicator of cell debris or other cell constituents that were released by the mechanical force.

Weakening or rupture of cell walls also explains the enhanced extractability with DME (see Fig. 6). Micrographs of the feedstocks (Online Resource 5) additionally documented a noticeable increase in particle surface roughness and cell disintegration with higher pretreatment intensity.

Overall, the feedstocks can be classified with regard to their resistance to cryo-milling in the order NG $>$ PT $>$ SA $>$ AP (from highest to lowest resistance) for the current experiments.

\subsection{Lipid extraction}

Chloroform/methanol(/water) systems, such as the commonly applied Bligh and Dyer method (1:2:0.8 chloroform/metha$\mathrm{nol} /$ water with an initial solvent-to-sample ratio of $3: 1(\mathrm{v} / \mathrm{m})$ [86]), are often recognized as "gold standard" [62]. The original Folch method works with a different ratio of 2:1 chloroform/methanol $(\mathrm{v} / \mathrm{v})$ and a solvent-to-sample ratio of 20:1 ( $/ \mathrm{m})$ [47]. It showed to be superior to the Bligh \& Dyer in the determination of total lipid contents for samples of marine tissues with lipid contents above $2 \%$ [87]. In the current work, an increased solvent-to-sample ratio of 100:1 was applied in order to prevent solubility-limitation. This method was expected to provide a reliable value for total lipid contents of the different microalgae samples. Nonetheless, it is considered unsuitable for large scale industrial application, because of health and environmental risks associated with the use of chloroform [88]. It should also be noted that a complete lipid removal is usually only achieved by applying a high number of consecutive extractions (due to a lowered solvent mixture's capacity with an increasing amount of nonpolar lipids and a decreasing oil concentration in the starting material [5]). However, extracting the remaining lipids often requires a disproportionately high number of additional extraction steps [5] and would not add much value here.

As GRAS (generally recognized as safe) alternative, an ethanol-based reference extraction was tested (adapted from [89]), but not further considered due to low total oil recoveries (Online Resources 3, 4).

Previous studies reported the salvation of additional organic compounds (e.g., proteins or polyphenols) in DME $[26,90]$. In order to mitigate these effects on yield determination, crude oil samples were solved in chloroform/methanol and processed similarly to the Soxhlet method (mixed with salt solution and consecutively separated in two phases) for the removal of unsaponifiable lipids and non-lipid material [91, 92]. Nonetheless, extracts were dark green to brown in color and thus obviously contaminated with algal pigments to a certain extent. Those pigments were most likely carotenoids, as chlorophylls tend to remain in the polar phase [54]. It was also noted that especially during the Soxhlet extractions, after solvent evaporation, a dark, brown to black residue was found, which was hardly soluble. Residual proteins that accumulated in the phase boundary have previously been reported [93, 94] and could be a part of this "insoluble fraction." Regarding the overall mass balance, the influence of pigments and residual proteins is expected to be small.

Overall, DME extracted 5-19\% of total lipids without further pretreatment and 17-50\% with additional cryo-milling (Fig. 6). In both scenarios, PT was the best performing species, followed by SA, NG, and AP. This did not correlate with the total lipid contents of the species. AP, NG, and PT showed very similar total oil contents, but AP and NG yields (knifemilled) with DME were at only 5-8\% of total oil in contrast to $19 \%$ for PT. It is consequently assumed that the specific properties of the tested algae species were a major influential factor for the differences in observed extraction performances with DME.

\subsubsection{Effects of milling on DME extractions}

Cryo-milling reduced particle sizes drastically (Fig. 5 and Table 2) and did thus not only damage algae cells, but also enlarge the specific surface area of the samples [6]. Direct contact between solvent and solute and an enlarged contact area (shorter diffusion paths) can enhance overall extraction performance $[95,96]$. Yap et al. described monophasic algae extraction systems as binary in nature with a fast lipid recovery from ruptured cells, followed by a slow, linear, diffusiondriven extraction from intact cells [18]. For each of the batch trials, by using long contact times with constant shaking, the formation of equilibrium between solvent and solute was allowed and kinetic limitation should be avoided.

However, it was still found that extraction yields were greatly enhanced after additionally cryo-milling the algae 
feedstocks (Fig. 6). This indicates that cell walls of the dried algae formed a strong barrier to DME. In particular, yields between knife- and cryo-milled samples of the DME extractions increased by factors of $2.0<2.3<2.6<3.5$ for $\mathrm{SA}<\mathrm{NG}$ $<$ PT $<$ AP.

Interestingly, changes in extraction yields after cryomilling do not match with the relative or absolute changes in particle sizes. As an example, SA was the 2nd most-affected species by milling and additionally exhibited the smallest absolute particle size after milling. Nevertheless, it showed the lowest increase in oil yield with the cryo-milling pretreatment.

In experiments with Saccharomyces cerevisiae, Spiden et al. demonstrated that PSD measurements were insufficient to quantify cell rupture, as they could not detect major flaws in cell walls (which might allow a release of metabolites) [97]. Also, in the present case, neither size reduction nor absolute particle size or a combination of both parameters could be directly linked to the degree of cell rupture and thus be utilized to predict extraction performances.

\subsubsection{Study implications and limitations}

To the authors' knowledge, most of the applied species have not been tested with DME so far. Hoshino et al. [34] previously worked with wet AP in a fixed-bed system, but focused on a simultaneous dewatering and oil extraction. Consequently, solvent amounts and extraction system were different from the given conditions.

Opposing to the presented results, similar extraction efficiencies between DME and alternative solvents were reported previously, including chloroform/methanol mixtures $[29,31]$. With regard to hexane or $\mathrm{scCO}_{2}, \mathrm{DME}$ was even found to excel those in several works with various biomasses [34, 98, 99].

Also, the displayed need for cryo-milling to maximize extraction performance is somewhat in contrast to literature [29-31]. As a recent example, Kanda et al. investigated the DME extraction of microalgae species with a rigid, bio-mineralized cell wall. They concluded that pretreatment was not needed to obtain satisfactory extraction yields with DME [33].

As previous studies differ in multiple major processing parameters, such as algae species, mode of extraction (fixedbed vs batch), solvent-to-sample ratio, and feedstock water contents, a direct comparison is highly problematic. The presented DME batch experiments were conducted to reveal species-specific differences between various microalgae rather than obtaining a maximum oil yield. They were performed with relatively low amounts of solvent and long contact time in order to ensure equilibrium between solvent and solute. Further optimization of the extraction was not carried out.

Previous works showed that solvent-to-sample ratio is a key factor for maximizing oil recoveries. DME consumption was found to be positively correlated to lipid yields in both, fixed-bed [29, 30, 33, 100] and batch [101] extractions. As an example, Boonnoun et al. reported an increase in oil yield by a factor of 6 after changing the amount of DME from 6 to $200 \mathrm{~g}$ when extracting Haematococcus pluvialis [30]. Although it was demonstrated that DME extractions can work with ratios of 2.0-8.7 $\mathrm{g} \mathrm{DME} \mathrm{g}^{-1}$ dry mass [99, 102, 103], during most fixed-bed extractions, solvent-to-sample ratios of up to $890 \mathrm{~g}$ $\mathrm{g}^{-1}$ dry mass were applied [34]. This equals to about 500 $9000 \mathrm{~g}$ of solvent per $\mathrm{g}$ of lipid [25]. One of the few batch studies, which showed good results with regard to the reference treatment (hexane), used a solvent-to-sample ratio of roughly $160 \mathrm{~g} \mathrm{~g}^{-1}$ dry mass for maximum extraction of Euglena gracilis in comparison to $10 \pm 1.5 \mathrm{~g} \mathrm{~g}^{-1}$ here [101].

In the current setup, a limited solubility (due to low solvent-to-sample ratios) might explain the lower overall extraction efficiency with cryo-milled samples. The solubility of lipids is owed to a number of interacting factors, such as oil composition and lipids arrangement, which strongly vary with algae species. Nevertheless, this explanation cannot cover the pretreatment-induced differences between knife- and cryo-milled algae. In the latter case, a similar quantity of DME solved more than double the amount of oil. As an example, for PT the amount of DME per lipids extracted changed from $565 \mathrm{~g} \mathrm{~g}^{-1}$ for knife-milled samples to $210 \mathrm{~g} \mathrm{~g}^{-1}$ after cryo-milling.

In this context, the downsides of high amounts of solvent should also be touched briefly. Energy requirements for pumping and DME recovery increases with the amount of solvent applied. Moreover, if 5\% of DME is lost during an extraction cycle as stated by Oshita et al. [104], it adds up to $10-450 \mathrm{~g}$ of DME lost per g oil extracted for the reported 200-9000 g of solvent per g of lipid (literature and own values). Especially for biodiesel-focused approaches (e.g., [33, $34,105]$ ) such ratios may raise questions about sustainability, as DME is regarded as alternative fuel itself [106].

As another major influential factor, the initial water contents of feedstocks must be taken into account. Algae with roughly $74-95 \%$ water were used in previous studies [24, $30,32,100,101]$. This is advantageous with regard to a final application [19, 20], but water is expected to have a promoting or at least influencing effect on the overall extraction. On the one hand, it is partly solved by DME and is suspected to change the solvent mixture's polarity [25]. On the other hand, due to the mutual solubility, cell wall penetration, and consecutive salvation of lipid compounds might be facilitated. In addition, water transporting mechanisms of living cells could also affect the extraction in comparison to dried feedstocks.

In experiments with the brown seaweed Undaria pinnatifida, Billakanti et al. reported a decrease of DME yields 
by about $6 \%$ of total lipids when comparing wet to freezedried samples [60]. Although this is a rather small difference compared to the presented results, the possibility of water being a main reason for the low extraction efficiencies cannot be ruled out.

As discussed, the conducted experiments differ from previous studies in multiple key parameters. It is consequently not recommended to use the present results as a basis of comparison for DME extraction efficiency.

\subsection{Fatty acid compositions}

Each of the tested species showed a unique fatty acid profile (Table 3). Regarding the results of total lipid extraction, AP and SA results were well in accordance with literature [36, 107, 108].

For PT, a predominance of $\mathrm{C} 16: 1$ and $\mathrm{C} 16: 0$ and a lack in C18 fatty acids were found. Also, a high share of EPA was confirmed in this species, which may vary with culture age and conditions [42, 43, 109, 110].

The measured fatty acid profile of NG strongly differs from other works. A composition of mainly $\mathrm{C} 16: 0$ and $\mathrm{C} 16: 1$ with small amounts of $\mathrm{C} 14: 0$ and $\mathrm{C} 18: 1 \mathrm{n} 9$ and around $1 \%$ of C18:3n3 was reported $[63,111]$. The latter, however, was dominant in this study with a share of $42 \%$. Also, in literature, EPA yielded between 2.5 and $14 \%$ (for $\mathrm{N}$ starved and replete cultures) [63] in contrast to $0.4 \%$ here. It is consequently suspected that subspecies and/or culture conditions of the extracted NG were fundamentally different or that the culture was heavily contaminated.

In general, saturated and monounsaturated fatty acids with 14-20 C-atom chains are preferred for biodiesel applications $[38,112-114]$. AP and PT oils contained the highest amounts of C16:0 and C16:1 and also small shares of C18:1n9. With combined ratios of saturated and monounsaturated fatty acids of $73 \%$ and $81 \%$, respectively, those oils could be suitable as biodiesel feedstock.

As another major point of interest, PUFA, such as linoleic acid (C18:2n6), $\alpha$-linolenic acid (C18:3n3), eicosapentaenoic acid (EPA, C20:5n3), and docosahexaenoic acid (DHA, C22:6n3) were examined.

Total amounts of PUFA among the tested feedstocks were highest in NG (56\%), followed by SA (55\%), AP (27\%), and PT (19\%).

PUFA can be found in various organisms as parts of membranes or storage organelles or as precursors for many biologically active eicosanoids - mainly in the form of glycolipids, phospholipids, sphingolipids, and lipoproteins [42, 115]. For photosynthetic organisms in standard conditions, phospholipids and glycolipids are mostly present in the endomembrane system and the plastid, respectively [110].

PUFA are entirely derived from the diet and essential for human health. A $\omega-6$ to $\omega-3$ fatty acid ratio of $\leq 5: 1$ is generally recommended by health officials, which is often not met by typical western diets [116]. PUFA-rich products can help to balance out nutrient ratios or even for the treatment of illnesses and mental disorders [116, 117].

Of the named PUFA, especially C18:3n 3 was very abundant in NG and SA oils with about $42 \%$ of total oil. C18:2n6 made up between 12 and $14 \%$ for AP, $\mathrm{NG}$, and SA. However, both fatty acids can also be found in many vegetable oils, as well as in nuts, eggs, dairy, and meat [118].

As "more interesting" fatty acids, GLA, DHA, and EPA were examined. GLA is incorporated into infant formula and used to treat several diseases, e.g., atopic eczema [119]. DHA and EPA are included in therapies in order to prevent dementia [42]. EPA has further shown effectiveness in the treatment or prevention of cardiovascular diseases, high blood pressure, different forms of cancer, and schizophrenia, among others $[42,120,121]$.

DHA was not present in relevant amounts and only AP showed meaningful GLA quantities around $13 \%$. EPA was very abundant in PT oil with around $16 \%$.

Although total PUFA quantities were high for NG and SA, AP and PT seemed to be more suitable biorefinery candidates. They showed high levels of lipids usable for biodiesel conversion, as well as a substantial portion of valuable GLA and EPA, respectively. Furthermore, they have the potential to provide other high-value side products, such as phycocyanin (AP) [122] or fucoxanthin (PT) [81].

Concerning DME extraction applications, PT is recommended for further trials. SA also showed good overall yields, but a less favorable lipid profile and AP and NG demonstrated to be least compatible with DME.

\subsubsection{Effects of extraction procedure on fatty acid compositions}

It was previously hypothesized that DME preferably extracts saturated and monounsaturated fatty acids, such as C16:0 and C16:1 [25] suitable for biodiesel purposes.

With regard to the total relative amounts of saturated and monounsaturated fatty acids, a preferred extraction of DME could not be verified. However, in most cases, the DME extracted oil was characterized by higher shares of C14:0, C16:0, and C16:1 fatty acids. A preferential extraction of C14:0, C16:0, and C18:0 species with DME in comparison to Bligh and Dyer, hexane, and $\mathrm{scCO}_{2}$ was also previously reported by Hoshino et al during the extraction of Aurantiochytrium limacinum [31].

At the same time, it also became apparent that the used algae species interacted differently with the applied solvents and thereby influenced oil compositions. As an example, during the treatment of AP, the relative C16:0 amount was 
roughly $10 \%$ higher when DME was applied instead of chloroform/methanol. For SA, on the contrary, the relative C16:0 content changed from about $14 \%$ with DME to about $22 \%$ during Soxhlet.

Solvents (and procedures) showed to have an effect on the oil composition in the current work. The properties of the applied algae species and the specific interaction with the solvents seemed to be another determining factor for relative fatty acid contents in the resulting oils.

\subsubsection{Effects of milling on fatty acid compositions}

Cryo-milling increased the share of total PUFA during DME extraction for each species. Overall, relative PUFA recoveries were increased between $1.1 \%$ (SA) and $7.9 \%$ (PT) by cryomilling. The most remarkable increase was observed for the relative EPA content in PT and accounted for roughly $7 \%$.

According to literature, EPA is typically found in all membrane lipids of this species [110]. Since most PUFA are integrated as structural parts of membranes and organelles [42], these results are a strong indicator for advanced cell disruption and facilitated access of the solvent to inner cell compounds and building blocks.

As the intensive cryo-milling pretreatment led to increases in relative PUFA yields and changed the properties of the produced oils, no evidence was found that pressurized DME could compensate for the pretreatment in the current setup.

\section{Conclusion}

The present work showed that liquefied dimethyl ether can be a valuable solvent for biorefineries. Although working with low amounts of solvent in an unoptimized one-stage batch extraction, up to $50 \%$ of total oil could be recovered. DME extracted oils were characterized by increased relative proportions of C14:0, C16:0, and C16:1 fatty acids.

Phaeodactylum tricornutum proved to be most suitable with DME concerning extraction yields and content of valuable fatty acids in the current setup. Its oil was characterized by a high content of EPA in combination with biodieselrelevant fatty acids. Yields of Nannochloropsis gaditana and Arthrospira platensis were significantly lower and Scenedesmus almeriensis showed good recoveries but a less favorable fatty acid profile.

The applied cryo-milling pretreatment reduced particle sizes and simultaneously enhanced the DME yields significantly by factors of $2-3.5$ for each species. It also helped to increase the ratios of PUFA in DME extracted oils. Hence, for the tested extractions, an intense cell-disrupting pretreatment was needed in order to optimize DME performance. It is assumed that algae species and water content strongly influenced this outcome.
As each microalgae feedstock exhibited specific morphological traits that interacted differently with pretreatments and solvents, the authors are convinced that there is no general answer to the question which algae species or solvent is "the best." Future extraction systems will have to be tested and adjusted with regard to biomass properties and desired products. However, the easy oil separation and dewatering ability are expected to make DME a versatile contender for future lipid extraction applications.

Acknowledgments The authors would like to thank Gero C. Becker for versatile and continuing support, as well as Dr. Klaus Schwadorf and Dr. Josefine Hildebrand for analytical assistance. Lastly, we would like to thank Reinhold Ruess and the whole technical department for their enduring help.

Funding Open Access funding enabled and organized by Projekt DEAL.

\section{Compliance with ethical standards}

Conflict of interest The authors declare that they have no conflict of interest.

Open Access This article is licensed under a Creative Commons Attribution 4.0 International License, which permits use, sharing, adaptation, distribution and reproduction in any medium or format, as long as you give appropriate credit to the original author(s) and the source, provide a link to the Creative Commons licence, and indicate if changes were made. The images or other third party material in this article are included in the article's Creative Commons licence, unless indicated otherwise in a credit line to the material. If material is not included in the article's Creative Commons licence and your intended use is not permitted by statutory regulation or exceeds the permitted use, you will need to obtain permission directly from the copyright holder. To view a copy of this licence, visit http://creativecommons.org/licenses/by/4.0/.

\section{References}

1. Eing C, Goettel M, Straessner R, Gusbeth C, Frey W (2013) Pulsed Electric field treatment of microalgae-benefits for microalgae biomass processing. IEEE Trans Plasma Sci 41(10): 2901-2907. https://doi.org/10.1109/TPS.2013.2274805

2. Schenk PM, Thomas-Hall SR, Stephens E, Marx UC, Mussgnug JH, Posten C, Kruse O, Hankamer B (2008) Second Generation biofuels: high-efficiency microalgae for biodiesel production. Bioenerg Res 1(1):20-43. https://doi.org/10.1007/s12155-0089008-8

3. Wijffels RH, Barbosa MJ (2010) An outlook on microalgal biofuels. Science 329(5993):793-796. https://doi.org/10.1126/ science.1189139

4. Cuellar-Bermudez SP, Aguilar-Hernandez I, Cardenas-Chavez DL, Ornelas-Soto N, Romero-Ogawa MA, Parra-Saldivar R (2015) Extraction and purification of high-value metabolites from microalgae: essential lipids, astaxanthin and phycobiliproteins. Microb Biotechnol 8(2):190-209. https://doi.org/10.1111/17517915.12167

5. Cooney M, Young G, Nagle N (2009) Extraction of bio-oils from microalgae. Sep Purif Rev 38(4):291-325. https://doi.org/10. 1080/15422110903327919 
6. Meireles M, Angela A (eds) (2009) Extracting bioactive compounds for food products: theory and applications. Contemporary food engineering. CRC Press, Boca Raton

7. Pollet P, Davey EA, Ureña-Benavides EE, Eckert CA, Liotta CL (2014) Solvents for sustainable chemical processes. Green Chem 16(3):1034-1055. https://doi.org/10.1039/c3gc42302f

8. Lee SY, Cho JM, Chang YK, Oh YK (2017) Cell disruption and lipid extraction for microalgal biorefineries: a review. Bioresour Technol 244(2):1317-1328. https://doi.org/10.1016/j.biortech. 2017.06.038

9. Cequier-Sánchez E, Rodríguez C, Ravelo AG et al (2008) Dichloromethane as a solvent for lipid extraction and assessment of lipid classes and fatty acids from samples of different natures. J Agric Food Chem 56(12):4297-4303. https://doi.org/10.1021/ jf073471e

10. Jeevan Kumar SP, Vijay Kumar G, Dash A, Scholz P, Banerjee R (2017) Sustainable green solvents and techniques for lipid extraction from microalgae: a review. Algal Res 21:138-147. https://doi. org/10.1016/j.algal.2016.11.014

11. Catchpole O, Moreno T, Montañes F, Tallon S (2018) Perspectives on processing of high value lipids using supercritical fluids. J Supercrit Fluids 134:260-268. https://doi.org/10.1016/j. supflu.2017.12.001

12. Ramalakshmi K, Raghavan B (1999) Caffeine in coffee: its removal. Why and how? Crit Rev Food Sci Nutr 39(5):441-456. https://doi.org/10.1080/10408699991279231

13. Andrich G, Nesti U, Venturi F, Zinnai A, Fiorentini R (2005) Supercritical fluid extraction of bioactive lipids from the microalga Nannochloropsis sp. Eur J Lipid Sci Technol 107(6): 381-386. https://doi.org/10.1002/ejlt.200501130

14. Crampon C, Mouahid A, Toudji S-AA, Lépine O, Badens E (2013) Influence of pretreatment on supercritical CO2 extraction from Nannochloropsis oculata. J Supercrit Fluids 79:337-344. https://doi.org/10.1016/j.supflu.2012.12.022

15. Safi C, Camy S, Frances C, Varela MM, Badia EC, Pontalier PY, Vaca-Garcia C (2014) Extraction of lipids and pigments of Chlorella vulgaris by supercritical carbon dioxide: influence of bead milling on extraction performance. J Appl Phycol 26(4): 1711-1718. https://doi.org/10.1007/s10811-013-0212-3

16. Solana M, Rizza CS, Bertucco A (2014) Exploiting microalgae as a source of essential fatty acids by supercritical fluid extraction of lipids: comparison between Scenedesmus obliquus, Chlorella protothecoides and Nannochloropsis salina. J Supercrit Fluids 92:311-318. https://doi.org/10.1016/j.supflu.2014.06.013

17. Mouahid A, Crampon C, Toudji S-AA, Badens E (2016) Effects of high water content and drying pre-treatment on supercritical $\mathrm{CO}_{2}$ extraction from Dunaliella salina microalgae: experiments and modelling. J Supercrit Fluids 116:271-280. https://doi.org/10. 1016/j.supflu.2016.06.007

18. Yap BHJ, Crawford SA, Dumsday GJ, Scales PJ, Martin GJO (2014) A mechanistic study of algal cell disruption and its effect on lipid recovery by solvent extraction. Algal Res 5:112-120. https://doi.org/10.1016/j.algal.2014.07.001

19. Roux J-M, Lamotte H, Achard J-L (2017) An overview of microalgae lipid extraction in a biorefinery framework. Energy Procedia 112:680-688. https://doi.org/10.1016/j.egypro.2017.03. 1137

20. Barclay W, Apt K (2013) 4 - Strategies for bioprospecting microalgae for potential commercial applications. In: Richmond A, Hu Q (eds) Handbook of microalgal culture. John Wiley \& Sons, Ltd, Oxford, pp 69-79

21. O'Neil MJ (ed) (2013) The Merck index: an encyclopedia of chemicals, drugs, and biologicals, 15. ed. RSC Publ. Royal Soc. of Chemistry, Cambridge

22. Ihmels EC, Lemmon EW (2007) Experimental densities, vapor pressures, and critical point, and a fundamental equation of state for dimethyl ether. Fluid Phase Equilib 260(1):36-48. https://doi. org/10.1016/j.fluid.2006.09.016

23. EFSA Panel on Food Contact Materials, Enzymes, Flavourings and Processing Aids (2009) Scientific Opinion on the safety in use of dimethyl ether as an extraction solvent. EFSA J 984:113. https://doi.org/10.2903/j.efsa.2009.984

24. Kanda H, Li P, Yoshimura T, Okada S (2013a) Wet extraction of hydrocarbons from Botryococcus braunii by dimethyl ether as compared with dry extraction by hexane. Fuel 105:535-539. https://doi.org/10.1016/j.fuel.2012.08.032

25. Bauer MC, Kruse A (2019) The use of dimethyl ether as an organic extraction solvent for biomass applications in future biorefineries: a user-oriented review. Fuel 254:115703. https:// doi.org/10.1016/j.fuel.2019.115703

26. Catchpole OJ, Tallon SJ, Grey JB, Fenton K, Fletcher K, Fletcher AJ (2007) Extraction of lipids from aqueous protein-rich streams using near-critical dimethylether. Chem Eng Technol 30(4):501510. https://doi.org/10.1002/ceat.200600351

27. Florentino de Souza Silva AP, Costa MC, Colzi Lopes A et al (2014) Comparison of pretreatment methods for total lipids extraction from mixed microalgae. Renew Energy 63:762-766. https:// doi.org/10.1016/j.renene.2013.10.038

28. Cheng C-H, Du T-B, Pi H-C et al (2011) Comparative study of lipid extraction from microalgae by organic solvent and supercritical $\mathrm{CO}_{2}$. Bioresour Technol 102(21):10151-10153. https://doi. org/10.1016/j.biortech.2011.08.064

29. Kanda H, Li P (2011) Simple extraction method of green crude from natural blue-green microalgae by dimethyl ether. Fuel 90(3): 1264-1266. https://doi.org/10.1016/j.fuel.2010.10.057

30. Boonnoun P, Kurita Y, Kamo Y et al (2014) Wet extraction of lipids and astaxanthin from Haematococcus pluvialis by liquefied dimethyl ether. J Nutr Food Sci 4(5). https://doi.org/10.4172/ 2155-9600.1000305

31. Hoshino R, Murakami K, Wahyudiono W, Machmudah S, Okita Y, Ohashi E, Kanda H, Goto M (2016) Economical wet extraction of lipid from labyrinthula Aurantiochytrium limacinum by using liquefied dimethyl ether. Engl J 20(4):145-153. https://doi.org/10. 4186/ej.2016.20.4.145

32. Kanda H, Li P, Ikehara T, Yasumoto-Hirose M (2012) Lipids extracted from several species of natural blue-green microalgae by dimethyl ether: extraction yield and properties. Fuel 95:88-92. https://doi.org/10.1016/j.fuel.2011.11.064

33. Kanda H, Hoshino R, Murakami K, Wahyudiono, Zheng Q, Goto M (2020) Lipid extraction from microalgae covered with biomineralized cell walls using liquefied dimethyl ether. Fuel 262:116590. https://doi.org/10.1016/j.fuel.2019.116590

34. Hoshino R, Ogawa M, Murakami K et al (2017) Extraction of lipids from wet Arthrospira platensis by liquefied dimethyl ether. Solvent Extr Res Dev 24(1):47-60. https://doi.org/10.15261/serdj. 24.47

35. Fang Y, Gu S, Liu S, Zhang J, Ding Y, Liu J (2018) Extraction of oil from high-moisture tuna liver by subcritical dimethyl ether: feasibility and optimization by the response surface method. RSC Adv 8(5):2723-2732. https://doi.org/10.1039/C7RA12948C

36. Sánchez JF, Fernández JM, Acién FG, Rueda A, Pérez-Parra J, Molina E (2008) Influence of culture conditions on the productivity and lutein content of the new strain Scenedesmus almeriensis. Process Biochem 43(4):398-405. https://doi.org/10.1016/j. procbio.2008.01.004

37. Borowitzka MA (2018) Biology of Microalgae. In: Levine IA, Fleurence J (eds) Microalgae in health and disease prevention. Academic Press, London, pp 23-72

38. Rodolfi L, Chini Zittelli G, Bassi N, Padovani G, Biondi N, Bonini G, Tredici MR (2009) Microalgae for oil: strain selection, induction of lipid synthesis and outdoor mass cultivation in a low-cost 
photobioreactor. Biotechnol Bioeng 102(1):100-112. https://doi. org/10.1002/bit.22033

39. Simionato D, Sforza E, Corteggiani Carpinelli E, Bertucco A, Giacometti GM, Morosinotto T (2011) Acclimation of Nannochloropsis gaditana to different illumination regimes: effects on lipids accumulation. Bioresour Technol 102(10):6026 6032. https://doi.org/10.1016/j.biortech.2011.02.100

40. Mitra M, Patidar SK, George B, Shah F, Mishra S (2015) A euryhaline Nannochloropsis gaditana with potential for nutraceutical (EPA) and biodiesel production. Algal Res 8:161-167. https:// doi.org/10.1016/j.algal.2015.02.006

41. Macías-Sánchez MD, Fernandez-Sevilla JM, Fernández FA et al (2010) Supercritical fluid extraction of carotenoids from Scenedesmus almeriensis. Food Chem 123(3):928-935. https:// doi.org/10.1016/j.foodchem.2010.04.076

42. Guedes AC, Amaro HM, Barbosa CR, Pereira RD, Malcata FX (2011) Fatty acid composition of several wild microalgae and cyanobacteria, with a focus on eicosapentaenoic, docosahexaenoic and $\alpha$-linolenic acids for eventual dietary uses. Food Res Int 44(9):2721-2729. https://doi.org/10.1016/j.foodres.2011.05.020

43. Yang Y-H, Du L, Hosokawa M et al (2017) Fatty acid and lipid class composition of the microalga Phaeodactylum tricornutum. J Oleo Sci 66(4):363-368. https://doi.org/10.5650/jos.ess16205

44. Belay A (2013) Biology and industrial production of Arthrospira (Spirulina). In: Richmond A, Hu Q (eds) Handbook of microalgal culture. John Wiley \& Sons, Ltd, Oxford, pp 339-358

45. Holman BWB, Malau-Aduli AEO (2013) Spirulina as a livestock supplement and animal feed. J Anim Physiol Anim Nutr 97(4): 615-623. https://doi.org/10.1111/j.1439-0396.2012.01328.x

46. Laurens LML, Dempster TA, Jones HDT, Wolfrum EJ, van Wychen S, McAllister JSP, Rencenberger M, Parchert KJ, Gloe LM (2012) Algal biomass constituent analysis: method uncertainties and investigation of the underlying measuring chemistries. Anal Chem 84(4):1879-1887. https://doi.org/10.1021/ac202668c

47. Folch J, Lees M, Sloane Stanley GH (1957) A simple method for the isolation and purification of total lipides from animal tissues. J Biol Chem 226(1):497-509

48. Zhu CJ, Lee YK (1997) Determination of biomass dry weight of marine microalgae. J Appl Phycol 9(2):189-194. https://doi.org/ 10.1023/A:1007914806640

49. Laurens LML (2015) Laboratory Analytical Procedure (LAP): summative mass analysis of algal biomass - Integration of Analytical Procedures. https://www.nrel.gov/docs/fy16osti/ 60943.pdf. Accessed 22 Jul 2020

50. van Wychen S, Laurens LML (2015) Laboratory Analytical Procedure (LAP): determination of total solids and ash in algal biomass. https://www.nrel.gov/docs/fy16osti/60956.pdf. Accessed 22 Jul 2020

51. Biller P, Ross AB, Skill SC, Lea-Langton A, Balasundaram B, Hall C, Riley R, Llewellyn CA (2012) Nutrient recycling of aqueous phase for microalgae cultivation from the hydrothermal liquefaction process. Algal Res 1(1):70-76. https://doi.org/10.1016/j. algal.2012.02.002

52. Yada RY (2004) Handbook of food proteins. Woodhead Publishing in food science and technology. CRC Press; Woodhead Pub, Boca Raton, Cambridge Eng.

53. Sepúlveda C, Acién FG, Gómez C, Jiménez-Ruíz N, Riquelme C, Molina-Grima E (2015) Utilization of centrate for the production of the marine microalgae Nannochloropsis gaditana. Algal Res 9: 107-116. https://doi.org/10.1016/j.algal.2015.03.004

54. Hita Peña E, Robles Medina A, Jiménez Callejón MJ, Macías Sánchez MD, Esteban Cerdán L, González Moreno PA, Molina Grima E (2015) Extraction of free fatty acids from wet Nannochloropsis gaditana biomass for biodiesel production. Renew Energy 75:366-373. https://doi.org/10.1016/j.renene. 2014.10.016
55. López Barreiro D, Zamalloa C, Boon N, Vyverman W, Ronsse F, Brilman W, Prins W (2013) Influence of strain-specific parameters on hydrothermal liquefaction of microalgae. Bioresour Technol 146:463-471. https://doi.org/10.1016/j.biortech.2013.07.123

56. Ryckebosch E, Bruneel C, Termote-Verhalle R, Goiris K, Muylaert K, Foubert I (2014) Nutritional evaluation of microalgae oils rich in omega-3 long chain polyunsaturated fatty acids as an alternative for fish oil. Food Chem 160:393-400. https://doi.org/ 10.1016/j.foodchem.2014.03.087

57. Chisti Y (2007) Biodiesel from microalgae. Biotechnol Adv 25(3):294-306. https://doi.org/10.1016/j.biotechadv.2007.02.001

58. Wawrik B, Harriman BH (2010) Rapid, colorimetric quantification of lipid from algal cultures. J Microbiol Methods 80(3):262266. https://doi.org/10.1016/j.mimet.2010.01.016

59. Romero García JM, Acién Fernández FG, Fernández Sevilla JM (2012) Development of a process for the production of L-aminoacids concentrates from microalgae by enzymatic hydrolysis. Bioresour Technol 112:164-170. https://doi.org/10.1016/j. biortech.2012.02.094

60. Billakanti JM, Catchpole OJ, Fenton TA, Mitchell KA, MacKenzie AD (2013) Enzyme-assisted extraction of fucoxanthin and lipids containing polyunsaturated fatty acids from Undaria pinnatifida using dimethyl ether and ethanol. Process Biochem 48(12):1999-2008. https://doi.org/10.1016/j.procbio. 2013.09.015

61. Peña MA, Reíllo A, Escalera B, Bustamante P (2006) Solubility parameter of drugs for predicting the solubility profile type within a wide polarity range in solvent mixtures. Int J Pharm 321(1-2): 155-161. https://doi.org/10.1016/j.ijpharm.2006.05.014

62. Breil C, Abert Vian M, Zemb T, Kunz W, Chemat F (2017) "Bligh and Dyer" and Folch methods for solid-liquid-liquid extraction of lipids from microorganisms. Comprehension of solvatation mechanisms and towards substitution with alternative solvents. Int J Mol Sci 18(4). https://doi.org/10.3390/ijms18040708

63. Simionato D, Block MA, La Rocca N et al (2013) The response of Nannochloropsis gaditana to nitrogen starvation includes de novo biosynthesis of triacylglycerols, a decrease of chloroplast galactolipids, and reorganization of the photosynthetic apparatus. Eukaryot Cell 12(5):665-676. https://doi.org/10.1128/EC.0036312

64. Gao B, Chen A, Zhang W, Li A, Zhang C (2017) Co-production of lipids, eicosapentaenoic acid, fucoxanthin, and chrysolaminarin by Phaeodactylum tricornutum cultured in a flat-plate photobioreactor under varying nitrogen conditions. J Ocean Univ China 16(5):916-924. https://doi.org/10.1007/s11802-0173174-2

65. Scott GT (1943) The mineral composition of chlorella pyrenoidosa grown in culture media containing varying concentrations of calcium, magnesium, potassium, and sodium // The mineral composition of chlorella pyrenoidosa grown in culture media containing varying concentrations of calcium, magnesium, potassium, and sodium. J Cell Physiol 21(3):327-338. https://doi. org/10.1002/jcp. 1030210310

66. Rocha JMS, Garcia JEC, Henriques MHF (2003) Growth aspects of the marine microalga Nannochloropsis gaditana. Biomol Eng 20(4-6):237-242. https://doi.org/10.1016/S1389-0344(03)000613

67. Berges JA, Franklin DJ, Harrison PJ (2002) Evolution of an artificial seawater medium: improvements in enriched seawater, artificial water over the last two decades. J Phycol 37(6):1138-1145. https://doi.org/10.1046/j.1529-8817.2001.01052.x

68. Miranda JR, Passarinho PC, Gouveia L (2012) Pre-treatment optimization of Scenedesmus obliquus microalga for bioethanol production. Bioresour Technol 104:342-348. https://doi.org/10.1016/ j.biortech.2011.10.059 
69. López Barreiro D, Bauer M, Hornung U, Posten C, Kruse A, Prins W (2015) Cultivation of microalgae with recovered nutrients after hydrothermal liquefaction. Algal Res 9:99-106. https://doi.org/ 10.1016/j.algal.2015.03.007

70. D’Hondt E, Martín-Juárez J, Bolado S et al. (2017) Cell disruption technologies. In: Microalgae-based biofuels and bioproducts. Woodhead Publishing animprint of Elsevier, Kindlington, pp 133-154

71. Zheng H, Yin J, Gao Z, Huang H, Ji X, Dou C (2011) Disruption of Chlorella vulgaris cells for the release of biodiesel-producing lipids: a comparison of grinding, ultrasonication, bead milling, enzymatic lysis, and microwaves. Appl Biochem Biotechnol 164(7):1215-1224. https://doi.org/10.1007/s12010-011-9207-1

72. Beacham TA, Bradley C, White DA, Bond P, Ali ST (2014) Lipid productivity and cell wall ultrastructure of six strains of Nannochloropsis: Implications for biofuel production and downstream processing. Algal Res 6:64-69. https://doi.org/10.1016/j. algal.2014.09.003

73. Scholz MJ, Weiss TL, Jinkerson RE, Jing J, Roth R, Goodenough U, Posewitz MC, Gerken HG (2014) Ultrastructure and composition of the Nannochloropsis gaditana cell wall. Eukaryot Cell 13(11):1450-1464. https://doi.org/10.1128/EC.00183-14

74. Voigt J, Stolarczyk A, Zych M, Malec P, Burczyk J (2014) The cell-wall glycoproteins of the green alga Scenedesmus obliquus. The predominant cell-wall polypeptide of Scenedesmus obliquus is related to the cell-wall glycoprotein gp3 of Chlamydomonas reinhardtii. Plant Sci 215-216:39-47. https://doi.org/10.1016/j. plantsci.2013.10.011

75. Mendez L, Mahdy A, Ballesteros M, González-Fernández C (2014) Methane production of thermally pretreated Chlorella vulgaris and Scenedesmus sp. biomass at increasing biomass loads. Appl Energy 129:238-242. https://doi.org/10.1016/j. apenergy.2014.04.110

76. Francius G, Tesson B, Dague E, Martin-Jézéquel V, Dufrêne YF (2008) Nanostructure and nanomechanics of live Phaeodactylum tricornutum morphotypes. Environ Microbiol 10(5):1344-1356. https://doi.org/10.1111/j.1462-2920.2007.01551.x

77. Le Costaouëc T, Unamunzaga C, Mantecon L et al (2017) New structural insights into the cell-wall polysaccharide of the diatom Phaeodactylum tricornutum. Algal Res 26:172-179. https://doi. org/10.1016/j.algal.2017.07.021

78. Martínez-Sanz M, Fabra MJ, Gómez-Mascaraque LG et al (2018) Structural effects of microalgae additives on the starch gelatinisation process. Food Hydrocoll 77:257-269. https://doi. org/10.1016/j.foodhyd.2017.10.002

79. Cerón MC, Campos I, Sánchez JF et al (2008) Recovery of lutein from microalgae biomass: development of a process for Scenedesmus almeriensis biomass. J Agric Food Chem 56(24): 11761-11766. https://doi.org/10.1021/jf8025875

80. Fernández-Sevilla JM, Acién Fernández FG, Molina Grima E (2010) Biotechnological production of lutein and its applications. Appl Microbiol Biotechnol 86(1):27-40. https://doi.org/10.1007/ s00253-009-2420-y

81. Zhang W, Wang F, Gao B, Huang L, Zhang C (2018) An integrated biorefinery process: stepwise extraction of fucoxanthin, eicosapentaenoic acid and chrysolaminarin from the same Phaeodactylum tricornutum biomass. Algal Res 32:193-200. https://doi.org/10.1016/j.algal.2018.04.002

82. Mehariya S, Iovine A, Di Sanzo G et al (2019) Supercritical fluid extraction of lutein from Scenedesmus almeriensis. Molecules 24(7). https://doi.org/10.3390/molecules24071324

83. Henriques M, Silva A, Rocha J (2007) Extraction and quantification of pigments from a marine microalga: a simple and reproducible method. In: Mendez-Vilas A (ed) Communicating current research and educational topics and trends in applied microbiology. FORMATEX, Badajoz, pp 586-593
84. Ryckebosch E, Bermúdez, Cuéllar SP, Termote-Verhalle R et al (2014) Influence of extraction solvent system on the extractability of lipid components from the biomass of Nannochloropsis gaditana. J Appl Phycol 26(3):1501-1510. https://doi.org/10. 1007/s10811-013-0189-y

85. Teuling E, Schrama JW, Gruppen H, Wierenga PA (2017) Effect of cell wall characteristics on algae nutrient digestibility in Nile tilapia (Oreochromis niloticus) and African catfish (Clarus gariepinus). Aquaculture 479:490-500. https://doi.org/10.1016/j. aquaculture.2017.06.025

86. Bligh EG, Dyer WJ (1959) A rapid method of total lipid extraction and purification. Can J Biochem Physiol 37(8):911-917. https:// doi.org/10.1139/o59-099

87. Iverson SJ, Lang SL, Cooper MH (2001) Comparison of the Bligh and Dyer and Folch methods for total lipid determination in a broad range of marine tissue. Lipids 36(11):1283-1287. https:// doi.org/10.1007/s11745-001-0843-0

88. Lorente E, Farriol X, Salvadó J (2015) Steam explosion as a fractionation step in biofuel production from microalgae. Fuel Process Technol 131:93-98. https://doi.org/10.1016/j.fuproc.2014.11.009

89. Fajardo AR, Cerdán LE, Medina AR, Fernández FGA, Moreno PAG, Grima EM (2007) Lipid extraction from the microalga Phaeodactylum tricornutum. Eur J Lipid Sci Technol 109(2): 120-126. https://doi.org/10.1002/ejlt.200600216

90. Kanda H, Li P, Makino H (2013b) Production of decaffeinated green tea leaves using liquefied dimethyl ether. Food Bioprod Process 91(4):376-380. https://doi.org/10.1016/j.fbp.2013.02.001

91. Schneiter R, Daum G (2006) Extraction of yeast lipids. Methods Mol Biol 313:41-45. https://doi.org/10.1385/1-59259-958-3:041

92. Ibáñez González MJ, Robles Medina A, Grima EM et al (1998) Optimization of fatty acid extraction from Phaeodactylum tricornutum UTEX 640 biomass. J Am Oil Chem Soc 75(12): 1735-1740. https://doi.org/10.1007/s11746-998-0325-z

93. Pohndorf RS, Camara ÁS, Larrosa APQ, Pinheiro CP, Strieder MM, Pinto LAA (2016) Production of lipids from microalgae Spirulina sp: influence of drying, cell disruption and extraction methods. Biomass Bioenergy 93:25-32. https://doi.org/10.1016/ j.biombioe.2016.06.020

94. Kumar RR, Rao HP, Arumugam M (2015) Lipid extraction methods from microalgae: a comprehensive review. Front Energy 2:457. https://doi.org/10.3389/fenrg.2014.00061

95. Oshita K, Takeda K, Takaoka M et al (2010) Dewatering of Electroplating sludge using dimethyl ether. J Environ Syst Eng (Doboku Gakkai Ronbunshuu G) 66(3):96-102. https://doi.org/ 10.2208/jscejg.66.96

96. Öhrman OGW, Pettersson E (2013) Dewatering of biomass using liquid bio dimethyl ether. Dry Technol 31(11):1267-1273. https:// doi.org/10.1080/07373937.2013.788018

97. Spiden EM, Scales PJ, Kentish SE, Martin GJO (2013) Critical analysis of quantitative indicators of cell disruption applied to Saccharomyces cerevisiae processed with an industrial high pressure homogenizer. Biochem Eng J 70:120-126. https://doi.org/10. 1016/j.bej.2012.10.008

98. Li P, Kanda H, Makino H (2014) Simultaneous production of biosolid fuel and bio-crude from vegetal biomass using liquefied dimethyl ether. Fuel 116:370-376. https://doi.org/10.1016/j.fuel. 2013.08.020

99. Catchpole O, Ryan J, Zhu Y, Fenton K, Grey J, Vyssotski M, MacKenzie A, Nekrasov E, Mitchell K (2010) Extraction of lipids from fermentation biomass using near-critical dimethylether. $\mathrm{J}$ Supercrit Fluids 53(1-3):34-41. https://doi.org/10.1016/j.supflu. 2010.02.014

100. Kanda H, Li P, Goto M, Makino H (2015) Energy-saving lipid extraction from wet Euglena gracilis by the low-boiling-point solvent dimethyl ether. Energies 8(1):610-620. https://doi.org/ 10.3390/en8010610 
101. Sakuragi K, Li P, Aoki N, Otaka M, Makino H (2016) Oil recovery from wet Euglena gracilis by shaking with liquefied dimethyl ether. Fuel Process Technol 148:184-187. https://doi.org/10. 1016/j.fuproc.2016.03.005

102. Catchpole OJ, Tallon SJ, Grey JB, Fletcher K, Fletcher AJ (2008) Extraction of lipids from a specialist dairy stream. J Supercrit Fluids 45(3):314-321. https://doi.org/10.1016/j.supflu.2008.01. 004

103. Boonnoun P, Shotipruk A, Kanda H, Goto M (2018) Optimization of rubber seed oil extraction using liquefied dimethyl ether. Chem Eng Commun 17:1-8. https://doi.org/10.1080/00986445.2018. 1522502

104. Oshita K, Takaoka M, S-i K et al (2010) Extraction of PCBs and water from river sediment using liquefied dimethyl ether as an extractant. Chemosphere 78(9):1148-1154. https://doi.org/10. 1016/j.chemosphere.2009.12.017

105. Mubarak M, Shaija A, Suchithra TV (2014) A review on the extraction of lipid from microalgae for biodiesel production. Algal Res 7:117-123. https://doi.org/10.1016/j.algal.2014.10.008

106. Fleisch TH, Basu A, Gradassi MJ et al (1997) Dimethyl ether: a fuel for the 21st century. Stud Surf Sci Catal 107:117-125. https:// doi.org/10.1016/S0167-2991(97)80323-0

107. Griffiths MJ, van Hille RP, Harrison STL (2012) Lipid productivity, settling potential and fatty acid profile of 11 microalgal species grown under nitrogen replete and limited conditions. J Appl Phycol 24(5):989-1001. https://doi.org/10.1007/s10811-0119723-y

108. Golmakani M-T, Mendiola JA, Rezaei K, Ibáñez E (2012) Expanded ethanol with $\mathrm{CO}_{2}$ and pressurized ethyl lactate to obtain fractions enriched in $\gamma$-linolenic acid from Arthrospira platensis (Spirulina). J Supercrit Fluids 62:109-115. https://doi.org/10. 1016/j.supflu.2011.11.026

109. Alonso DL, Belarbi E-H, Fernández-Sevilla JM, Rodríguez-Ruiz J, Grima EM (2000) Acyl lipid composition variation related to culture age and nitrogen concentration in continuous culture of the microalga Phaeodactylum tricornutum. Phytochemistry 54(5): 461-471. https://doi.org/10.1016/S0031-9422(00)00084-4

110. Abida H, Dolch L-J, Meï C, Villanova V, Conte M, Block MA, Finazzi G, Bastien O, Tirichine L, Bowler C, Rébeillé F, Petroutsos D, Jouhet J, Maréchal E (2015) Membrane glycerolipid remodeling triggered by nitrogen and phosphorus starvation in Phaeodactylum tricornutum. Plant Physiol 167(1):118-136. https://doi.org/10.1104/pp.114.252395

111. Radakovits R, Jinkerson RE, Fuerstenberg SI, Tae H, Settlage RE, Boore JL, Posewitz MC (2012) Draft genome sequence and genetic transformation of the oleaginous alga Nannochloropis gaditana. Nat Commun 3:686. https://doi.org/10.1038/ ncomms 1688

112. Yen H-W, Hu I-C, Chen C-Y, Ho SH, Lee DJ, Chang JS (2013) Microalgae-based biorefinery-from biofuels to natural products. Bioresour Technol 135:166-174. https://doi.org/10.1016/j. biortech.2012.10.099

113. Robles-Medina A, González-Moreno PA, Esteban-Cerdán L, Molina-Grima E (2009) Biocatalysis: towards ever greener biodiesel production. Biotechnol Adv 27(4):398-408. https://doi.org/ 10.1016/j.biotechadv.2008.10.008

114. Doan TTY, Sivaloganathan B, Obbard JP (2011) Screening of marine microalgae for biodiesel feedstock. Biomass Bioenergy 35(7):2534-2544. https://doi.org/10.1016/j.biombioe.2011.02. 02

115. Leu S, Boussiba S (2014) Advances in the Production of highvalue products by microalgae. Ind Biotechnol 10(3):169-183. https://doi.org/10.1089/ind.2013.0039

116. Rubio-Rodríguez N, Beltrán S, Jaime I, de Diego SM, Sanz MT, Carballido JR (2010) Production of omega-3 polyunsaturated fatty acid concentrates: a review. Innovative Food Sci Emerg Technol 11(1):1-12. https://doi.org/10.1016/j.ifset.2009.10.006

117. Lee KW, Lip GYH (2003) The role of omega-3 fatty acids in the secondary prevention of cardiovascular disease. Q J Med 96(7): 465-480. https://doi.org/10.1093/qjmed/hcg092

118. Béligon V, Christophe G, Fontanille P, Larroche C (2016) Microbial lipids as potential source to food supplements. Curr Opin Food Sci 7:35-42. https://doi.org/10.1016/j.cofs.2015.10. 002

119. Horrobin DF (1992) Nutritional and medical importance of gamma-linolenic acid. Prog Lipid Res 31(2):163-194. https:// doi.org/10.1016/0163-7827(92)90008-7

120. Bajpai P, Bajpai P (1993) Eicosapentaenoic acid (EPA) production from microorganisms: a review. J Biotechnol 30(2):161-183. https://doi.org/10.1016/0168-1656(93)90111-Y

121. Ward OP, Singh A (2005) Omega-3/6 fatty acids: Alternative sources of production. Process Biochem 40(12):3627-3652. https://doi.org/10.1016/j.procbio.2005.02.020

122. Kumar D, Dhar DW, Pabbi S, Kumar N, Walia S (2014) Extraction and purification of C-phycocyanin from Spirulina platensis (CCC540). Indian J Plant Physiol 19:184-188. https:// doi.org/10.1007/s40502-014-0094-7

Publisher's Note Springer Nature remains neutral with regard to jurisdictional claims in published maps and institutional affiliations. 